Competition and Relational Contracts:

The Role of Unemployment as a Disciplinary Device

Martin Brown, Armin Falk and Ernst Fehr

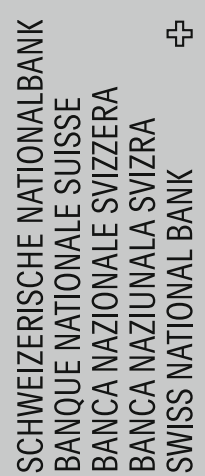

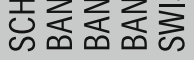

n

(7)

$\frac{1}{2}$

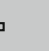

宸崖

的的美

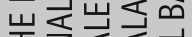

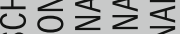

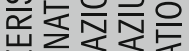

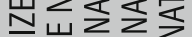


The views expressed in this paper are those of the author(s) and do not necessarily represent those of the Swiss National Bank. Working Papers describe research in progress. Their aim is to elicit comments and to further debate.

ISSN 1660-7716 (printed version)

ISSN 1660-7724 (online version)

๑ 2008 by Swiss National Bank, Börsenstrasse 15, P.0. Box, CH-8022 Zurich 


\title{
Competition and Relational Contracts: \\ The Role of Unemployment as a Disciplinary Device
}

\author{
Martin Brown*, Armin Falk**, Ernst Fehr***
}

February 2008

\begin{abstract}
When unemployment prevails, relations with a particular firm are valuable for workers. As a consequence, a worker may adhere to an implicit agreement to provide high effort, even when performance is not third-party enforceable. But can implicit agreements - or relational contracts - also motivate high worker performance when the labor market is tight? We examine this question by implementing an experimental market in which there is an excess demand for labor and the performance of workers is not third-party enforceable. We show that relational contracts emerge in which firms reward performing workers with wages that exceed the going market rate. This motivates workers to provide high effort, even though they could shirk and switch firms. Our results thus suggest that unemployment is not a necessary device to motivate workers. We also discuss how market conditions affect relational contracting by comparing identical labor markets with excess supply and excess demand for labor. Long-term relationships turn out to be less frequent when there is excess demand for labor compared to a market characterized by unemployment. Surprisingly though, this does not compromise market performance.
\end{abstract}

JEL: D82, J3, J41, E24, C9

Keywords: Relational Contracts, Involuntary Unemployment.

*Swiss National Bank, Börsenstrasse 15, CH-8022 Zurich, martin.brown(a)snb.ch. **University of Bonn, Adenauerallee 24-42, D-53113 Bonn, armin.falk@uni-bonn.de. *** Institute for Empirical Research in Economics, University of Zurich, Blumlisalpstrasse 10, CH8006 Zurich, efehr@iew.unizh.ch. We thank Bentley MacLeod, Christian Zehnder, as well as seminar participants at the University of Zurich, the Swiss National Bank, IZA, MIT and the Centre d'Etudes d'Emploi for helpful comments. Franziska Heusi and Mirja Königsberg provided excellent research assistance. 


\section{Introduction}

Firms and workers often rely on relational contracts which specify mutual obligations in implicit, non-verifiable agreements (Williamson 1975; MacLeod, 2000; Baker et. al., 2002). The widespread use of implicit agreements is arguably due to the fact that complete, explicit labor contracts are costly to design and enforce. Relational contracts need to be self-enforcing, in the sense that both firms and workers voluntarily adhere to their obligations. This can only be achieved, however, if the future value of the relationship is sufficiently high for both parties (Bull, 1987). Obviously, the value of a particular employment relationship to the firm or worker will depend on labor market conditions. In a market characterized by high unemployment, a worker who has a job is disciplined not to shirk, as shirking would certainly jeopardize his or her future employment prospects (Shapiro and Stiglitz, 1984; for empirical support, see Brown et al. 2004). If, however, there is full employment, a worker may be more tempted to shirk, as he can always switch to another firm, should he be caught.

In this paper we empirically examine the emergence and effectiveness of relational contracts under full employment. The main question we address is whether unemployment as a disciplining device is a necessary precondition for relational contracting or whether relational contracts form even in the absence of unemployment. Labor market models suggest that relational contracts can sustain high performance of workers independent of market conditions. MacLeod and Malcolmson (1998) show that implicit agreements between firms and employees can be sustained in a market with unemployment or full employment. They show that it is merely the nature of relational contracts that changes with market conditions: As proposed by Shapiro and Stiglitz (1984), relational contracts are characterized by simple rents, i.e. efficiency wages, when workers are threatened by unemployment. In contrast, under full employment, firms must offer relation-specific quasi-rents to workers in order to motivate high performance. In MacLeod and Malcolmson (1998) post-effort bonus payments generate such quasi-rents within a relationship. Indeed, from a theoretical point of view, any remuneration package, which offers deferred payments, such as "seniority wages" (Lazear, 1982) or explicit "bonding" (Carmichael, 1985) can sustain an implicit agreement under full employment. Quasi rents are not restricted to the payment of deferred compensation, however. Relational contracts without deferred payments can motivate effort under high demand for agents, as long as they generate "insider" 
information for principals. Boot and Thakor (1994), e.g., show that banking relationships in which a bank offers below-market interest rates to well performing borrowers can motivate high effort from borrowers even if alternative spot-market financing is available. It is profitable for banks to offer below-market interest rates, because information on prior behavior gives them superior information on the quality of a borrower.

So far there is little evidence to support the conjecture that self-enforcing relational contracts can be maintained under full-employment. In this paper, we therefore report evidence on an experimental labor market in which effort is not third-party enforceable and which is characterized by an excess demand for workers. First of all, we find that effective relational contracts do emerge under full employment. In line with the abovementioned theories, these relational contracts are based on the payment of quasi rents. These quasi rents accrue because firms reward well performing workers with wages that exceed those offered by "outside" firms. In other words, incumbent firms pay wages that exceed the going market rate, thus creating an incentive to provide high effort, for workers who could shirk and switch firms at any time. A potential explanation for why "outside" firms offer lower wages than a worker's current firm is based on the belief that workers who switch firms are more likely to provide low effort. In the results section we show in fact that incumbent firms expect higher effort than outside firms: After a contract was accepted, and before the worker chose his actual level of effort, we asked each firm what level of effort they expected from the worker. It turns out that expected effort is positively correlated with relationship duration, i.e., a relationship with a particular worker raises firms' expectations regarding worker behavior significantly, allowing them to offer better contract terms. Of course, high wage offers by incumbent firms only motivate money-maximizing workers if these offers are contingent on a worker's past performance. Our data suggests that this is indeed the case. The probability that a worker receives a high-wage offer by his incumbent firm in a given period depends strongly positively on his effort in the previous period. In particular, a worker who performs the maximum effort can almost be certain to receive a high-wage offer in the next period. Summarizing our main results we find that outside firms offer relatively low wages, inducing workers to fulfill the contracts of their current firms. Workers correctly anticipate that contract renewals, and thus future wages, are contingent on performance. As a consequence relations with well performing agents form and efficiency is relatively high. 
Additional to our main treatment we ran two control treatments. The first implements the same labor market as before but with third-party enforceable contracts. Since contract enforcement is not an issue in this market we can use this market as a benchmark to compare the wage offer policies and the frequency of long-term relations in our main treatment. It turns out that while in our main treatment incumbent firms pay higher wages than "outside" firms this is not the case in the market with third-party enforceable contacts. Moreover, relations are much more frequent in our main treatment than in the control treatment where relational contracting is possible as well. This allows us to causally establish that relationships are formed to solve contracting problems and not for other reasons, such as, e.g., convenience on the part of firms and workers. Our second control treatment is identical to our main treatment with the important difference that relational contracting is ruled out by design. Comparing this control treatment with our main treatment allows us to show that effort provision in our main treatment in fact reflects the presence of relational contracting. Effort levels in our main treatment are much higher, showing that relational contracting improves market performance substantially. Moreover, For example, while efforts sharply decrease towards the end of the experiment in our main treatment there is no such end-game effect in the control treatment.

The fact that (in our main treatment) relational contracting works well even in the absence of unemployment as a disciplining device does not imply that relational contracting is independent of market conditions and identical to a situation with unemployment. To shed light on the differences between relational contracting with excess demand vs. excess supply of workers we compare market outcomes in our experiment to that of Brown et al. (2004), where we implemented an identical labor market with exogenous unemployment. This allows a causal interpretation of the differences in relational contracting depending on market conditions. Several important differences can be observed: While relational contracts do emerge under full employment, we find that high-performing long-term employment relationships are less frequent than in the labor market with exogenous unemployment. In the presence of exogenous unemployment workers rarely terminate a relation and switch to another firm. This happens more often in the absence of unemployment. However, the lower number of relationships under full employment does not reduce aggregate market performance compared to markets with exogenous unemployment. This can be reconciled with higher wages in markets with excess demand for labor and reciprocal 
effort decisions on the part of workers. Wage differences across market conditions, however, are relatively small suggesting that relational contracting favors wage rigidities.

Several empirical studies in recent years have analyzed the role of deferred compensation or quasi rents for self-enforcing relational contracts. Studies of wage profiles within firms show that deferred payment schemes are frequent, and that these cannot be simply explained by productivity gains (Medoff and Abraham, 1980, Flabbi and Ichino, 2001; Dohmen, 2004). While these studies suggest that deferred payments are offered in order to provide incentives to workers, the used data sets typically do not allow identifying the relative importance of incentives versus a human capital explanation. Moreover, these studies do not analyze how the prevalence of deferred payments varies with competitive conditions in the labor market. Examining payment schemes of young workers in the US, MacLeod and Parent (2000) show that, controlling for job characteristics, bonus payments are more frequent in countries where the labor market is tight. Their data, however, cannot distinguish discretionary bonus payments from explicitly guaranteed ones. It is therefore unclear whether the observed bonus payments are actually components of relational contracts. Huck et al. (2004) provide experimental evidence that deferred compensation increases worker effort. However, in their experiment, firms and workers are randomly matched on a one-to-one basis. This means they cannot relate quasi rents to relational contracting or study how the prevalence and impact of quasi rents is related to labor market conditions.

Evidence on job tenure across business cycles suggests that employment relations may be more difficult to sustain when the labor market is tight. Examining data from 16 industrialized countries, Auer and Cazes (2000) find that job tenure drops when economic growth leads to high demand for labor. Moreover, examining worker-flow data from the United States, Bleakley et al. (1999) show that workers' switching behavior is responsible for this breakdown of long-term employment relationships. They find that there are significantly more voluntary quits by workers during expansionary periods of the business cycle than during recessions. However, these studies can hardly identify whether long-term employment is a result of relational contracts between firms and workers, specific human capital investment, or switching costs in the labor market. As a result, the fact that many employment relationships appear to collapse under full employment does not imply that it is implicit agreements that are falling apart. 
The paper is organized as follows. We present our experimental design in the next section. In Section 3 we discuss our behavioral predictions. In Section 4 we present and interpret our results on the emergence of relational contracts under full employment. In Section 5 we compare the frequency and enforcement power of relational contracts under full employment to that under exogenous unemployment. Section 6 concludes.

\section{Experimental design}

The experiment lasts 15 trading periods and each trading period has two stages: At stage 1 , firms make contract offers $[w, \tilde{e}]$ to workers, which specify a non-contingent wage $w$ and a desired effort $\tilde{e}$. At the second stage, the actual performance of the worker $e$ is determined. In addition, we ask each firm what level of effort they expect from the worker before they know the actually chosen level of effort. The posting and acceptance of contracts is conducted in a continuous auction involving all firms and workers. There are 10 firms and 7 workers in the market. As a worker can only trade with one firm in each period, the experiment implements an excess demand for workers.

\subsection{The Incomplete Contracts (IC) treatment}

In our main treatment, henceforth called the Incomplete Contracts (IC) treatment, contracts are not exogenously enforced. In this treatment, we allow workers to choose any feasible effort $e$, irrespective of the contractually proposed level $\tilde{e}$. Firms are the contract makers. A firm can make private or public offers. In the case of a private offer, the firm specifies the identification number (ID) of the worker with whom it wants to trade. Only this worker is informed about the offer. In the case of a public offer, all workers and all other firms are informed about the offer. As a consequence, all workers can accept a public offer. In a given trading period, firms can make as many private and public offers as they want to. As soon as a worker has accepted one of the offers, the firm which has made the offer is matched with this worker and informed of the ID of the worker. Each firm can hire one worker at most, and each worker can accept only one wage offer. Once an offer has been accepted, all of the firm's other outstanding offers are immediately removed from the market. At all times during a trading period, firms are informed about the workers still remaining in the market. This is done to prevent private offers to workers who have already concluded a contract. 
In the IC treatment, firms and workers have the possibility of trading repeatedly with each other. Technically, repeated transactions with the same trading partner are possible because subjects have fixed IDs throughout the experiment. Therefore, a firm can make offers to the same worker (same ID) in consecutive periods and, if the worker accepts the offers, a long-term relationship is established.

The material payoff of a firm per period is given by:

$$
\pi(w, e)=\left\{\begin{array}{cl}
10 \cdot e-w & , \text { if a contract is concluded } \\
0 & , \text { if no contract is concluded }
\end{array}\right.
$$

Likewise, the material payoff of a worker is given by:

$$
v(w, e)=\left\{\begin{array}{cl}
w-c(e) & , \text { if a contract is concluded } \\
5 & , \text { if no contract is concluded }
\end{array}\right.
$$

where $c(e)$ denotes the cost of supplying effort $e$.

The set of feasible effort and wage levels is given by $e \in[1,2, . ., 10]$ and $w \in$ $[1, \ldots, 100]$, respectively. The cost schedule for workers $c(e)$ is displayed in Table 1 . This shows that $c(e)$ is strictly increasing and exhibits increasing marginal costs.

\section{Insert Table 1 here}

Payoff functions, the number of firms and workers, the cost of effort, and the fact that there were 15 trading periods is common knowledge. At the end of each trading period, each participant is informed about the contract $[w, \tilde{e}]$ he or she has concluded, the performed effort level, $e$, their own payoff, the payoff of the trading partner and the ID of the trading partner. Participants then write this information on a separate sheet of paper to ensure that they are always fully informed about their own trading history.

\subsection{Control treatments}

In addition to the IC treatment we study two control treatments. In the Complete Contracts (C) treatment the proposed effort $\tilde{e}$ of the firm is exogenously enforced. Thus, if a worker accepts a contract $[w, \tilde{e}]$ at stage 1 of a period, then at stage 2 he is 
forced to perform $e=\tilde{e}$. Otherwise all procedures and parameters are identical to those in the IC treatment. In particular, all participants have fixed IDs so that a firm can establish a relationship with a particular worker (and vice versa). This control treatment generates benchmark results for the frequency of long-term relationships and for firms' contract offers when contracts are third-party enforceable.

Our second control treatment is called Incomplete Contracts Random ID (ICR) treatment. As in our main IC treatment, effort is not enforceable in this treatment. Different to the IC treatment, however, information conditions prevent firms and workers from establishing relationships. This is realized by randomly assigning IDs to participants in each period (both firms and workers). Participants are therefore unable to identify who they have traded with in the past and thus they cannot deliberately maintain relationships. This control treatment provides benchmark results on wages and effort performance when contracts are not third-party enforceable and relational contracts are not feasible.

\subsection{Procedures}

The experimental instructions were framed in a neutral goods market language, to avoid behavior based on participants' preconceptions about how the labor market works. Firms were called "buyers" and their contract offers were framed as "price offers" for a "desired quality". Workers were called "sellers" and their actual effort choice was framed as "actual quality".

The experiment was conducted using the "z-tree" software (Fischbacher, 2007). Prior to the 15 trading periods, participants completed two practice periods in order to get accustomed to the computer environment. In both practice periods, subjects only went through the first (bidding) stage of the experiment and no money could be earned during these periods.

We conducted five sessions of each treatment and thus a total of 15 sessions. Subjects were students from the University of Zurich and the ETH Zurich. No subject participated in more than one session, so that in total 255 subjects (17 in each session) participated in the experiment. On average, a session lasted 120 minutes and each subject earned roughly CHF $60(1$ Euro $=$ CHF 1.4673, \$US $1=$ CHF 1.4651 ; at the time the experiments were conducted). 


\section{Behavioral predictions}

All participants were informed that each session of our experiment would last exactly 15 periods. As a consequence, our three treatments constitute repeated games of finite length. In this section, we generate behavioral predictions for the three treatments, first assuming common knowledge of money maximizing behavior. We then derive predictions assuming incomplete information about workers' types.

\subsection{Money-maximizing behavior of all participants}

Assuming common knowledge of money-maximizing behavior, outcomes in our IC and ICR treatments are predicted to be inefficient. If workers are money-maximizing and effort is not enforceable, firms will anticipate that all workers will perform the minimal effort level $e=1$ in period 15 , no matter what the history of the experiment. Competing for workers, firms will bid each other up to the highest wage, which gives them a non-negative profit, anticipating that $e=1$. Firms will therefore offer a contract $[w, \tilde{e}]=[10,1]$ in period 15 . By backward induction, firms will offer the same contract in periods 1 through 14 and workers' performance will always be minimal.

These predictions for the IC and ICR treatments are in strong contrast to the $\mathbf{C}$ treatment where contracts are enforceable and thus (value-maximizing) full performance can be implemented. With common knowledge of money-maximizing behavior, firms in the $\mathrm{C}$ treatment will offer the contract which is most preferred by selfish workers. As the maximum effort $e=10$ leads to the highest surplus, firms will offer contracts which demand the maximum effort and a wage that ensures that workers reap the entire gains from trade. ${ }^{1}$ Thus with common knowledge of selfishness and rationality the equilibrium contract in each period of the $C$ treatment is $[w, \tilde{e}]=[100,10]$.

\subsection{Non identifiable "fair" workers}

Common knowledge of money-maximizing behavior among participants is questionable in our experiment. Experimental studies find that fairness concerns motivate the behavior of some subjects in gift-exchange games similar to that implemented in this experiment (Fehr et al., 1993; Fehr and Falk, 1999; Brown et al.,

\footnotetext{
${ }^{1}$ Since the marginal cost of effort is at most 3 , while the marginal revenue of effort for the firm is always 10 , the efficient effort level is given by $e=10$. Maximum earnings firms and workers can share from a single trade are $10 * 10-18=82$. As firms have no outside option, while workers have an outside option of 5 , the maximum gains from trade are $82-5=77$.
} 
2004) as well as in a wider range of economic settings (see e.g. Camerer, 2003). The importance of fairness motives in experiments is mirrored by worker behavior in the labor market. Interview studies with human resources managers suggest that the performance of workers is strongly affected by the fairness of their remuneration (Bewley, 1995; Blinder and Choi, 1990). Akerlof and Yellen (1990) provide a theoretical model in which workers' effort choice is dependent on the perceived fairness of their wages. More recently, social preferences have been integrated into general models of economic behavior (see, e.g., Fehr and Schmidt, 1999 or Falk and Fischbacher, 2006).

In the Appendix we offer behavioral predictions for our experiment, assuming that effort of some (non-identifiable) workers depends on the perceived fairness of wage offers. We apply a simplified version of the Fehr and Schmidt (1999) model in which individuals are assumed to be inequity-averse. More precisely, we assume that there is a share $p$ of fair workers who adhere to a contract $[w, \tilde{e}]$ if and only if it offers them at least a fair share of earnings: $w-c(\tilde{e}) \geq q \tilde{e}-w$. If the contract does not offer them an equal split of earnings, fair workers just maximize their monetary payoffs. We assume that the remaining share $1-p$ of workers maximize their monetary payoff. ${ }^{2}$

In the Appendix (Proposition A1), we show that, in the ICR treatment, firms can profitably offer non-minimal contracts $[w>10, \tilde{e}>1]$ only if there is a minimum share of fair-minded workers in the market $(p>.2)$. As participants are randomly assigned an ID at the beginning of every period, and they do not receive any information on the prior behavior of workers, the ICR essentially implements a series of one-shot transactions. In a one-period game a selfish worker will shirk, no matter what contract the firm offers. A fair worker will, however, adhere to the contract as long as the contract terms are fair. The presence of fair workers who provide the desired effort can therefore compensate for the potential loss from a selfish worker, as long as there are sufficiently many fair workers.

Under the assumption that some (non-identifiable) workers are fair, our IC treatment constitutes a repeated game of incomplete information. In such games, reputation concerns can motivate money-maximizing agents to imitate the behavior of non-money maximizing agents even if the horizon is finite (see Kreps et al., 1982 and Gächter and Falk, 2002). In the Appendix, we show that such reputation equilibria exist

\footnotetext{
${ }^{2}$ Brown (2004) analyzes our experiment applying the more general model of Fehr and Schmidt (1999). He replicates the qualitative findings derived in our Appendix.
} 
for our IC treatment in which money-maximizing workers imitate the behavior of fair workers by exerting high effort. In Proposition A2 of the Appendix, we derive a perfect Bayesian equilibrium in which incumbent firms in the IC treatment offer quasi-rents that are sufficient to motivate maximum effort from money-maximizing workers in all non-final periods. In this equilibrium, wages promised by incumbent firms exceed those of "outside" firms by more than the cost of desired effort $c(\tilde{e})$. Outside firms offer lower wages than incumbent firms because they believe that only money-maximizing workers will switch jobs. As outside firms offer low wages, money-maximizing workers will fulfill the contracts of their current firms if they expect that contract renewals, and thus future wages, are contingent on performance. In return, given that all workers adhere to contracts demanding maximum effort levels, it is profitable for incumbent firms to offer surplus-sharing wages. As the reputation of each worker is known only to his current employer, the self-enforcing agreement described here predicts long-term relationships between firms and workers. Further, as there is nothing to be gained for a moneymaximizing worker from adhering to a contract in the final period, these workers will shirk in period 15 . We therefore predict an "end-game" effect in the IC treatment, characterized by a drop in average effort provision by workers to the level of effort in the ICR treatment.

It is important to note that the "pooling" equilibrium described above is of course not unique. Further equilibria exist in which money-maximizing workers partially imitate the behavior of fair workers, or even shirk completely. Given the excess demand for labor, full provision of effort by money-maximizing workers in all non-final periods can only be sustained if the beliefs of outside firms induce them to offer lower wages than their current firms. Thus although full-imitating behavior by money-maximizing workers is feasible in our IC treatment, intuitively it would seem much more difficult to sustain than in a labor market where unemployment prevails.

The presence of some fair workers does not change the predictions for our $\mathbf{C}$ treatment. In this treatment, effort is third-party enforceable so that maximum effort is implemented even if all workers are money-maximizers. This will also be the case with some fair workers. Note further, that effort provision in the $\mathrm{C}$ treatment is not dependent on the formation of relationships. As a consequence we predict fewer long-term relationships in the $\mathrm{C}$ treatment than in the IC treatment.

Summing up, we predict three main qualitative outcomes for our experiment, in the presence of some (unidentifiable) fair workers. First, in the IC treatment, wages offered 
by incumbent firms are higher than those available to workers in the public market. Contract renewals with high wage offers are, however, contingent on a worker's past performance. Second, aggregate performance in the IC treatment is higher than in the ICR treatment, as money-maximizing workers perform non-minimally out of reputation concerns in the IC treatment, while only fair workers perform in the ICR. Third, the duration of labor relationships is longer in the IC than in the $\mathrm{C}$ treatment. In the $\mathrm{C}$ treatment, relationships are not necessary to maintain high effort and result only out of convenience or coincidence. In the IC treatment, firms and workers establish and maintain relationships strategically, in order to overcome the non-contractibility of effort.

\section{Relational contracts under full employment}

\subsection{Firms' wage and employment policies}

Our predictions suggest that, in the IC treatment, firms can motivate moneymaximizing workers to perform high effort if they reward well performing workers with better future wages than they can expect from outside firms. Figure 1 shows that this is the case. Private wage offers from incumbent firms are substantially higher than those offered on the public market. As firms typically make several offers in each period, ${ }^{3}$ we consider the highest public wage offered by each firm as well as the highest private wage offered by each firm to its current worker. The figure reports the mean of these highest "public" wages and highest "repeat" wages across firms by period.

\section{Insert Figure 1 here}

In the IC treatment, wages in the public market fluctuate at around 40 , while repeat offers from incumbent firms rise from under 50 in period 2 to 60 in period 13 . The difference between "repeat" and "public" wages therefore increases from 3.8 in period 2 to more than 20 from period 11 onwards. Wages in relationships must exceed the public market level by the cost of desired effort $\mathrm{c}(\tilde{e})$, in order to motivate money-maximizing workers to perform in the IC treatment. Aggregated over all periods, the difference

\footnotetext{
${ }^{3}$ In the IC treatment, firms made an average of 4.6 offers each per period.
} 
between repeat and public wages is 14.6. This difference suggests that on average money-maximizing workers have sufficient incentives to provide very high levels of effort in the IC treatment, Remember that, for effort levels $e=8,9,10$, the cost of effort is 12,15 and 18 respectively.

A multiple regression analysis confirms that the difference between repeat and public wages in the IC treatment is statistically significant. We pool the maximum public and repeat wage offers of each firm for each period of the IC treatment. We then regress these wages on a dummy variable, "Repeat offer", which is 1 for repeat offers and 0 for public offers, controlling for the period in which an offer was made. Column (1) of Table 2 reports the results of this regression, showing that the coefficient of "Repeat offer" is positive and significant at the 1 percent level. All results are based on robust standard errors adjusted for clustering on sessions.

Implicit agreements between firms and workers may explain higher wage offers by incumbent firms in the IC treatment. However, this could also be the result of a simple selection effect: As workers always accept the highest available wages, firms that manage to trade (and thus, by definition, manage to offer a repeat contract) are those that offer the highest wages. If this selection effect explains higher "repeat" wages, we should see an identical pattern in the $\mathrm{C}$ treatment, where contracts are enforceable. As Figure 1 shows, however, there is no difference between public and repeat wages in the $\mathrm{C}$ treatment at all. The figure thus suggests that it is the non-enforceability of contracts, which gives rise to the higher wages paid by incumbent firms in the IC treatment. This result is supported by a regression similar to that in column 1 in Table 2 using data of the $\mathrm{C}$ treatment. The respective coefficient of "Repeat offer" is insignificant $(\mathrm{p}=0.368)$.

We predicted that outside firms in the IC treatment offer lower wages than incumbent firms because they expect that workers who switch are less likely to be fairminded and will therefore provide lower effort. Our data shows that incumbent firms do indeed expect higher effort than outside firms. After a contract was accepted, and before the worker chose his actual level of effort, we asked each firm what level of effort they expected from the worker. A regression analysis shows that this expected effort is positively correlated with relationship duration after controlling for the wage offered by the firm. We conduct a linear regression analysis, in which "Expected effort" is related to the duration of the relationship between the particular firm and worker, controlling for the wage offered by the firm and the period in which the offer is made. "Relationship duration" is measured by the number of periods of consecutive trades 
between firm and worker, prior to the period in question. Column (2) of Table 2 reports the results of this analysis, and displays a positive and significant coefficient of "Relationship duration" on "Expected effort". This result suggests that controlling for wage payments, a relationship with a particular worker raises firms' expectations regarding worker behavior significantly, allowing them to make better wage offers. These expectations are largely justified in light of actual effort choices of switchers vs. non-switchers. Median effort of workers who break up a relation and switch to a new firm is 5 while median effort for workers who continue staying with their firm amounts to 9 . We also find that for a given wage offer, switchers provide significantly lower effort levels than non-switchers. ${ }^{4}$

Of course, high wage offers by incumbent firms motivate money-maximizing workers in the IC treatment only if these offers are contingent on a worker's past performance. Our data shows that this is indeed the case. The probability that a worker receives a high-wage repeat contract in period $t$ depends strongly positively on his effort in period $t-1$. In accordance with Figure 1, we define a high-wage contract as one in which the wage exceeds the mean of the best public wage offers across firms in that period. Our data shows that if a worker's effort level is less than 5 in period $t-1$, then his probability of getting a high-wage repeat offer is below 10 percent. For effort levels of 5 and 6 this probability rises to roughly 30 percent. For effort levels of 7, 8, 9 and 10, the probabilities are 62 percent, 70 percent, 82 percent and 90 percent, respectively. Thus, a worker who performs the maximum effort is virtually assured of receiving a high-wage offer.

Insert Table 2 here

A regression analysis confirms that firms practice a performance-contingent policy of offering high wages only to those workers who performed well in the past. Column 3 of Table 2 reports the results of a Probit analysis in which the probability of a highwage contract renewal is related to a worker's previous performance. The dependent variable is a dummy variable, which takes value 1 if a firm offers a private contract to its incumbent worker in period $t$ with a wage, which exceeds the average level in the public market. We regress this dummy variable on the effort of the worker in the prior

\footnotetext{
${ }^{4}$ Regression results are available on request.
} 
period, controlling for the period of the experiment and the length of the ongoing relationship between the firm and the worker (prior to period $t$ ). We include the previous length of the relationship as an explanatory variable, as firms may be more likely to hold on to a worker they have known for longer, even if he or she did not perform well in the prior period. We include the period of the experiment as an explanatory variable, as firms may be more inclined to hold on to a worker later in the experiment if they expect that more and more "fair" workers will be committed to relationships over the course of the experiment. This analysis yields a significant and positive coefficient of "Effort in prior period" with regard to the probability of a firm offering a high wage repeat contract. We summarize these findings in our first result:

Result 1: In the IC treatment firms expect higher efforts by incumbent workers than by switchers. Firms reward well performing incumbent workers with wages that exceed those offered by "outside" firms on the public market.

\subsection{Workers' effort}

The performance-contingent wage and employment policy of firms may motivate money-maximizing workers in the IC treatment to provide high effort. As a result, effort levels in the IC treatment should exceed those in the ICR treatment, where only fairmined workers perform non-minimal effort. We now examine whether this is the case by comparing performance in the IC treatment to that in the ICR treatment. ${ }^{5}$

Insert Figure 2 here

Figure 2 compares the distribution of effort levels in the IC and ICR treatments. The figure shows that maximum effort is the most frequent level of effort in the IC treatment, with workers performing at $e=10$ in more than 30 percent of all trades. Moreover, roughly 60 percent of all trades in the IC treatment are characterized by an effort level of $e \geq 7$. Remarkably, workers perform at minimal levels of effort, i.e., $e=1$, in only 15 percent of all trades (including final period effort choices), despite the fact that the high demand for labor assures them a future contract even if they shirk. As a

\footnotetext{
${ }^{5}$ In both treatments almost the maximum number of trades was realized. In the IC treatment 520 of 525 possible trades were realized, while in the ICR 523 trades were realized.
} 
result, the mean level of effort in the IC treatment is 6.7. In contrast to this, the maximum level of effort, $e=10$, occurs in only 7 percent of trades in the ICR treatment. The most frequent effort level in the ICR is $e=5$, which occurs in 21 percent of all trades. The mean level of effort in this treatment is 4.9. A Mann-Whitney test comparing the ten session averages confirms that performance in the IC treatment is significantly higher than in the ICR treatment $(\mathrm{p}<.028$, one sided).

In Table 3 we present a detailed regression analysis on the details of effort provision in the IC and ICR treatments. Columns 1 and 2 examine effort choices in the IC treatment. Columns 3 and 4 display an identical analysis of effort provision in the ICR treatment. The dependent variable in each regression is the actual effort of workers $e$. If some workers are fair in our sessions, we should find a positive coefficient for the "Wage" variable in both treatments. We also control for the phase of the experiment in which effort provision takes place. We do this by including the dummy variable "Final periods", which is 1 if a trade took place in period 11 or later and 0 otherwise. We do not expect time effects on effort in the ICR treatment, as this is essentially a series of one-shot games. By contrast, we expect time, i.e., the shadow of the future, to affect effort in the IC treatment, as reputation incentives for money-maximizing workers wear off towards the end of the experiment. We therefore predict a negative coefficient for "Final periods" in the IC treatment, while the coefficient should be insignificant in the ICR. Remember that we only expect high effort from money-maximizing workers in the IC treatment if a worker is in a relationship, which offers him better conditions than he can obtain from other firms. To capture the incentive effect of relationships in the IC treatment, we include the dummy variable "Private" in regressions (1) and (3). This variable is 1 if the contract offer was private and thus signaled the willingness of a firm to engage in a relationship with a particular worker. However, private offers may be viewed by some workers as a nice gesture, and thus lead to higher effort out of pure fairness or loyalty motives. In this case we would predict that private offers have an identical effect on effort in the IC and ICR treatments. If, in addition, private offers signal valuable future relationships in the IC treatment and thus create incentive effects for money-maximizing workers, we would expect that "Private" has a stronger effect in the IC than in the ICR. In regression (2), we examine our prediction that wages, which exceed public market wages are crucial to motivating performance in the IC treatment. We do this by including the dummy variable "Above public wage", which is 1 only if the wage exceeded the average wage paid in the public market. If wages above market 
level have an incentive effect in the IC treatment, we should obtain a positive coefficient for this variable in column (2). Of course, if public wages serve as a reference level for fair wages, we might also expect a positive impact from "Above public wage" in the ICR treatment. However, due to additional incentive effects in the IC treatment, we expect the coefficient of "Above public wage" to be higher in column (2) than in column (4).

\section{Insert Table 3 here}

The results presented in Table 3 confirm our main predictions. In all columns, the coefficient for "Wage" is positive, confirming the presence of some fair workers in our experiment. Moreover, in columns (1) and (2), the negative coefficients for "Final periods" confirm the presence of reputation incentives in the IC treatment. In contrast, the insignificant coefficients for "Final periods" in columns (3) and (4) show that there is no significant time effect with respect to effort in the ICR treatment. Comparing the coefficients for "Private" in columns (1) and (3), we see that private offers have only a weak effect in the ICR, but a strong positive effect in the IC treatment (both in terms of size and significance of the coefficient). A pooled analysis of effort in the IC and ICR treatments, displayed in column (5) of the table shows that the difference in impact of private offers is statistically significant. This result suggests that private offers signal valuable relationships in the IC treatment and thus create reputation incentives for money-maximizing workers to perform well. Comparing the coefficients for "Above public wage" in columns (2) and (4), we further see that contract offers with above market wages have a positive effect on effort in the IC treatment, but no effect in the ICR treatment. A pooled analysis of effort in the IC and ICR treatments, displayed in column (6) of the Table shows that the difference in impact of wages above the public market level is statistically significant. This result suggests that wages above market levels do provide incentives for (money-maximizing) workers to perform out of reputation concerns in the IC treatment. We summarize our findings on the determinants of effort in our next result:

Result 2: Effort provision in the IC treatment reflects the presence of reputational concerns and relational contracting: First, effort is significantly higher in the IC than the ICR treatment. Second, effort decreases in the final periods of the IC 
treatment but not in the ICR treatment. Third, in comparison to the ICR treatment, effort in the IC treatment depends much more strongly on private offers as well as wages, which exceed public market wages.

\subsection{Relationships and market performance}

Our results so far suggest that firms and workers manage to initiate relational contracts in the IC treatment. We should therefore observe repeated transactions between particular firms and workers in this treatment. Table 4 shows the proportion of relationships renewed in the IC treatment, by period. The table shows that the frequency of contract renewal rises from 26 percent in period 2 to more than 45 percent in period 11. Aggregated over all periods, relationships are continued in 38 percent of all possible instances in the IC treatment. The table also shows that contract renewals are much more frequent in the IC than in the $\mathrm{C}$ treatment. In the $\mathrm{C}$ treatment, the proportion of contract renewals is about 10 percent throughout the whole experiment. We argued above that contract renewals in both treatments may be a matter of pure convenience on the part of both firms and workers. However, in this case, we should see similar rates of renewals in the IC and $\mathrm{C}$ treatments. The fact that there are more contract renewals in the IC than in the $\mathrm{C}$ suggests that the objective to overcome contracting problems is the motivation for repeated interaction in the IC treatment. A one-sided Mann-Whitney test on session averages confirms the fact that contract renewals are significantly more frequent in the IC than in the $\mathrm{C}$ treatment $(\mathrm{p}<.004$, one-sided).

Insert Table 4 here

If long-term relationships are the result of successful and effective implicit agreements, we should also find that, in the IC treatment, effort levels and thus gains from trade are higher in long relationships than in short ones. Remember that the maximum effort level, $e=10$, results in total gains from trade of 77 points in our experiment.

One-shot transactions in the IC treatment generate average gains from trade of 39 points per period and thus just 51 percent of potential gains from trade. Medium-term relationships (2-10 periods) generate earnings of more than 67 points and thus roughly 87 percent of potential gains from trade per transaction. The longest relationships (11- 
15 periods), in comparison, yield average earnings of 76 points, i.e., 99 percent of possible gains from trade. A regression analysis confirms that gains from trade are positively related to the duration of a relationship in the IC treatment. We regress the gains from trade yielded per transaction on the final duration of the relationship between the firm and worker (measured in periods) and the period in which a transaction took place. Applying robust standard errors and clustering on sessions, we yield a coefficient of $3.5(\mathrm{p}=.002)$ for relationship duration.

Result 3: Long-term relationships form to overcome contracting problems. This can be inferred from the fact that relations are more frequent in the IC treatment than in the $C$ treatment. Moreover, in the IC treatment, gains from trade in long-term relations are higher than in shorter-term transactions.

\section{Labor market competition and relational contracts}

In the previous section, we showed that relational contracts emerge under full employment, although workers could shirk and switch firms at any time. This, however, does not mean that the effectiveness of relational contracts is completely unrelated to labor market conditions. In this section we compare the prevalence and contract enforcement power of relational contracts under full employment to those under exogenous unemployment. We do this by comparing the outcome of our experiment to that in Brown et al. (2004), where we conducted an identical experiment, but with inverted market conditions. Our former experiment implemented a market with 7 firms and 10 workers in each period, which are exactly the opposite market conditions to those in this study. Otherwise all experimental procedures and treatments in Brown et al. (2004) were identical to those of our current experiment. In the following, we contrast our IC treatment with the corresponding treatment in our former paper, which we henceforth call the IC* treatment. We will also briefly talk about the analogue to the ICR treatment, the ICR* treatment. The latter is exactly identical to the ICR treatment, except that in the $\mathrm{ICR}^{*}$ there was an excess supply of workers just as in the IC* treatment. Finally, the analogue to our $\mathrm{C}$ treatment is $\mathrm{C}^{*}$. In both treatments effort is third-party enforceable but market conditions are reversed, just as in IC vs. IC*.

In the Appendix, we derive predictions for the $\mathrm{IC}^{*}$ treatment and compare them to those for the IC. We derive that, given an identical share of fair workers $p$, the same 
level of aggregate effort can be sustained in the IC and IC* treatments (see Propositions A2 and A3). This is similar to MacLeod and Malcolmson (1998) who show for infinitely repeated games, that implicit contracts can be equally effective across market conditions. Our theoretical analysis suggests, first, that long-term relationships may be just as frequent in the IC* as they are in the IC treatment. Second it suggests that the aggregate effort level could be identical in the IC and IC* treatments. That said, being dynamic games of incomplete information, both the IC and IC* treatments have multiple equilibria. It is therefore an empirical question whether and how labor market conditions affect the enforcement power of relational contracting. Intuitively one might expect that is easier for firms to generate reputation incentives for money-maximizing workers in the IC* than the IC treatment. The reason is that, due to the excess supply of labor in the $\mathrm{IC}^{*}$, workers have no opportunity to switch firms if they shirk. Thus, while incumbent firms in the IC treatment must offer better terms than "outside firms", in the $\mathrm{IC}^{*}$, treatment simple rents (i.e. efficiency wages) already motivate effort on the part of money-maximizing workers. ${ }^{6}$

\subsection{Relationships and market conditions}

Figure 3 shows that long-term relationships are less frequent in the IC than in the IC* treatment. The figure displays the frequency of relationships by duration in the IC (full employment) and $\mathrm{IC}^{*}$ (unemployment) treatments. We distinguish between one-shot transactions (relationship was broken off after only 1 period), short-term relationships (2-5 periods), medium-term relationships (6-10 periods), and long-term relationships (11-15 periods). For each trade, we identify the final duration of the relationship in which it took place. The figure shows the share of all trades which occurred in one-shot, short-term, medium-term and long-term relationships. In the IC* treatment, over a third of all trades occur in relationships that lasted more than 10 periods. Moreover, in that treatment, 45 percent of all trades take place in relationships of more than 5 periods. By contrast, in the IC treatment only 25 percent of trades occur in relationships of more than 5 periods, and only 10 percent of all trades take place in relationships that lasted more than 10 periods. Due to strong variation in relationship duration across sessions, a

\footnotetext{
${ }^{6}$ Conversely, it is more difficult for firms to commit to a relationship in the IC* where labor is abundant than in the IC where workers are scarce. In the IC treatment an incumbent firm will strictly prefer to retain a performing worker, while in the $\mathrm{IC}^{*}$ it could be tempted to replace even a high performer with another freely available worker.
} 
statistical test shows, however, that these differences are only of borderline significance. $^{7}$

\section{Insert Figure 3 here}

Figure 3 suggests that strong competition for workers in the IC treatment makes it more difficult to sustain long term employment, as workers are no longer reliant on their current employer. This conjecture is confirmed by examining the break-up of relationships in the IC and IC* treatments. A contract renewal requires two decisions in our experiment. First, the firm has to offer a private contract to its former worker. Then, the worker has to choose this offer from the available private and public contracts. We expect that, in the IC treatment, repeat trades fail at the second stage: The break-up of relationships is due to workers not accepting contract offers made by their current firm. Summary statistics suggest that this is the case. In both the IC and IC* treatments, firms offer workers who performed their desired effort a renewed contract in 80 percent of the cases. In the IC*, however, only 2 percent of these offers are subsequently rejected by workers. By contrast in the IC treatment 28 percent of renewed contract offers are rejected. Looking closer at those instances where a worker rejects a renewed contract offer in the IC treatment we find that in 74 percent of the cases the worker accepted an outside offer with a wage at least as high as that offered by his current firm. An interesting finding arises from those cases, where a worker rejects a renewed offer by his current firm and accepts a lower wage from an outside firm. In 14 of these 16 cases the current firm had either lowered its wage offer or not increased it, compared to the prior period. Together, these findings suggest that workers broke off relationships, where they saw better outside opportunities, or (to a lesser extent) where their current firm did not meet their wage expectations.

\section{Insert Table 5 here}

The analyses presented in Table 5 confirm that relationships in the IC treatment break down due to worker rather than firm behavior. The table shows regression results concerning contract renewal behavior of firms and contract acceptance behavior of

\footnotetext{
${ }^{7}$ We group trades in one-shot and short term relationships ( $<6$ periods) and calculate the share of these trades for each session of the IC and IC* treatment. Using theses shares per session as observations we conduct a one-sided Mann-Whitney Test, which yields a p-value of .075 .
} 
workers in the IC and IC* treatments. We first regress the probability of a firm offering a repeat contract to its current worker based on the worker's effort, the period of the experiment, and a dummy variable "IC", which is 1 for trades in the IC treatment. If firms are equally likely to offer repeat contracts under both market conditions we should find that the coefficient of "IC" is insignificant in this analysis. Column (1) of the table reports marginal effect estimates calculated at the sample mean, with standard errors adjusted for clustering at the session level. In this regression we find that the IC dummy is insignificant. We then regress the probability of a worker accepting a repeat contract on the wage offered by the firm, the period of the experiment and the "IC dummy" (Column (2)). The significantly negative coefficient for the IC dummy, suggests that a contract offer from the incumbent firm had, on average, a 47 percent lower chance of being accepted by the worker in the IC treatment than in the IC* treatment.

\subsection{Market performance}

Given that we observe fewer long-term relationships in the IC treatment, does this mean that implicit agreements are less powerful, leading to lower aggregate effort provision than in the $\mathrm{IC}^{*}$ ? A comparison of labor market performance in the two treatments suggests that this is not the case. Figure 4 displays the mean level of effort in the IC and IC* treatments by period. ${ }^{8}$ The figure shows that average effort evolves almost identically in the IC and IC* treatments, rising from an initial level of about 6 to roughly 8 , and then suffering from an end-game effect which reduces effort to roughly 5. The end-game effect seems to set in somewhat earlier in the IC treatment, where competition for workers is more intense. This could be interpreted in the sense that, when workers are not disciplined by unemployment, contract enforcement may be more difficult. However, on aggregate, market performance in the IC treatment - with an average effort of 6.7 - is practically identical to that in the IC* treatment (6.9). This is supported by a two-sided Mann-Whitney Test $(\mathrm{p}=.421)$ on session averages suggesting that market conditions have no effect on market performance when contracts are not enforceable, and long-term relations are feasible.

\section{Insert Figure 4 here}

\footnotetext{
${ }^{8}$ The maximum number of trades was concluded in almost all sessions. Thus, a comparison of market performance between the treatments can concentrate on a comparison of mean effort levels and neglect potential differences in the frequency of trade.
} 
The fact that labor market performance is identical in the IC and IC*, although there are fewer long-term relationships in the IC, is surprising. One potential explanation rests on different wage levels and reciprocation on the part of workers. We actually find that the mean wage level in the IC treatment is 54.2 , compared to 40.1 in the IC* treatment. Higher wages are just reflecting stronger competition for labor in the IC treatment. Given the positive wage-effort relation prevalent in both treatments, higher wages lead to relatively high efforts in the IC treatment. This interpretation is supported by a comparison between the ICR and the ICR* treatment. Again reciprocally motivated workers should respond with higher efforts to the higher wages brought about by competition for labor. Figure 4 shows in fact that in the ICR treatment effort is higher than in the $\mathrm{ICR}^{*}$ treatment. Mean effort in the former is 4.9 and thus significantly higher than in the latter, where mean effort amounts to 3.3. This significant difference in effort levels is explained by higher wage levels in the ICR than in the ICR* treatment. In the ICR treatment, the mean wage level is 41.6 , while it is only 24.3 in the ICR* treatment.

We have just mentioned that mean wages in the IC treatment are higher than those in the IC* treatment (54.2, compared to 40.1). These differences reflect stronger competition for labor in the IC treatment suggesting that wages are flexible despite the existence of relational contracting. This seems to contradict theoretical models, which predict that relational contracts may isolate the distribution of surplus from changes in demand and supply for labor. MacLeod and Malcolmson (1998), e.g., predict that wage levels will be rigid in markets with relational contracting. To provide an accurate test whether wages are rigid in our experiment we have to compare the impact of market conditions on wages in markets with and without relational contracting. In other words, the differences in wages in markets where effort is third-party enforceable ( $\mathrm{C}$ and $\left.\mathrm{C}^{*}\right)$ provide us with a benchmark of wage flexibility. If wages are equally flexible in the presence of relational contracting (IC and IC*), this would suggest that relational contracting is not causing wage rigidity. It turns out that wage differences in markets with enforceable effort are much larger than in markets with relational contracting. The mean wage in our $\mathrm{C}$ treatment with no unemployment is 72.6 while it is 33.3 in the $\mathrm{C}^{*}$ treatment, i.e., in an identical market with unemployment. This difference clearly 
exceeds the difference between the IC and the $\mathrm{IC}^{*}$ treatment. ${ }^{9}$ Thus, while wages respond strongly to market conditions if contracts are enforceable, wages are relatively rigid in the presence of relational contracting.

Result 4: Under full employment, the frequency of long-term relationships in the labor market is lower than when unemployment prevails. Labor market performance, however, is not reduced under full employment. One explanation is that high demand for labor leads to higher wage levels, which induce higher effort on the part of reciprocally motivated workers. Finally, wages under relational contracting react much less to market conditions than markets where effort is third-party enforceable, suggesting that relational contracting favors wage rigidity.

\section{Concluding remarks}

In this paper, we examine the emergence and impact of relational contracts under full employment and compare them to a labor market with exogenous unemployment. We show that effective implicit agreements do emerge under full employment. Well performing workers receive higher wage offers from their current firm than from outside firms. This motivates workers to perform at a high level of effort, rather than to shirk and switch firms.

Confirming field studies (Bleakely et al., 1999), we find that workers are more likely to quit their jobs under full employment than when unemployment prevails, leading to fewer long-term employment relationships. However, our data also shows that shorter average tenure is not associated with a substantial undermining of relational contracts. In our experiment, effort levels are very similar across labor market conditions. In line with labor market models on relational contracting (MacLeod and Malcolmson, 1998) our results thus suggest that unemployment is not a necessary disciplining device in labor market segments, which suffer from contracting problems.

\footnotetext{
${ }^{9}$ One might argue, that this comparison does not take account of the differences in effort across treatments. Note, however, that we get the same result if we compare wages across treatments for given levels of effort.
} 


\section{References}

Akerlof, G.A. and J.L. Yellen (1990): "The Fair Wage-Effort Hypothesis and Unemployment", Quarterly Journal of Economics, 105, 2, 255-283.

Auer, P. and S. Cazes (2000): "The Resilience of the Long-Term Employment Relationship: Evidence from Industrialized Countries", International Labor Review, $139,4,379-408$.

Baker, G., R. Gibbons and K.J. Murphy (2002): "Relational Contracts and the Theory of the Firm", Quarterly Journal of Economics, 109, 1125-56.

Bewley, T.F. (1995): “A Depressed Labor Market as Explained by Participants", American Economic Review, 85, 2, 250-54.

Bleakley, H., A.E. Ferris and J.C. Fuhrer (1999) "New Data on Worker Flows during Business Cycles", New England Economic Review, July/August, 49-76.

Blinder, A.S. and D. Choi D (1990): "A Shred of Evidence on Theories of Wage Stickiness", The Quarterly Journal of Economics, 105, 4, 1003-1015.

Boot, A.W.A, and A.V. Thakor (1994): "Moral Hazard and Secured Lending in an Infinitely Repeated Credit Market Game”, International Economic Review, 35, 4, 899-920.

Brown, M. (2004) "Relational Contracts in Competitive Markets - An Experimental Analysis", PhD Thesis, University of Zurich.

Brown, M., A. Falk and E. Fehr (2004): "Relational Contracts and the Nature of Market Interactions", Econometrica, 72, 4, 747-780.

Bull, C., (1987): "The Existence of Self-Enforcing Implicit Contracts", Quarterly Journal of Economics, 102, 147-159.

Camerer, C. F. (2003): Behavioral Game Theory: Experiments in Strategic Interaction, Princeton, Princeton University Press.

Carmichael, L. (1985): “Can Unemployment be Involuntary?: Comment", American Economic Review, 75, 5, 1213-1214.

Dohmen, T. (2004): "Performance, seniority, and wages: formal salary systems and individual earnings profiles", Labour Economics (11), 741-763.

Falk, A. and U. Fischbacher (2006): A Theory of Reciprocity, Games and Economic Behavior, 54 (2), 293-315.

Fehr, E. and A. Falk (1999): "Wage Rigidity in a Competitive Incomplete Contract Market", Journal of Political Economy, 107, 1, 106-134. 
Fehr, E., G. Kirchsteiger, and A. Riedl (1993): "Does Fairness Prevent Market Clearing? An Experimental Investigation", Quarterly Journal of Economics, 108, 437-460.

Fehr, E. and K. Schmidt (1999): "A Theory of Fairness, Competition and Cooperation", Quarterly Journal of Economics 114, 817-868.

Fehr, E. and C. Zehnder (2005): "Reputation and Credit Market Formation", Mimeo, University of Zurich.

Fischbacher, U. (2007): "z-Tree: Zurich Toolbox for Readymade Economic Experiments, Experimental Economics 10, 171-178.

Flabbi, L. \& A. Ichino (2001): "Productivity, Seniority, and Wages: New Evidence from Personnel Data", Labour Economics, 8, 359-387.

Gächter, S. and Falk, A. (2002): "Reputation and Reciprocity - Consequences for the Labour Relation, Scandinavian Journal of Economics 104, 1-26.

Huck, S., A.J. Seltzer and B. Wallace (2004): "Deferred Compensation and Gift Exchange: An Experimental Investigation into Multi-Period Labor Markets", IZA

Kreps, D., P. Milgrom, J. Roberts and R. Wilson (1982): "Reputation and Imperfect Information", Journal of Economic Theory 27, 253-279.

Lazear, E. P. (1982): “Agency, Earnings Profiles, Productivity and Hours Restrictions”, American Economic Review, 71, 606-620.

MacLeod, W. B. (2000): “Complexity and Contract", Revue d'Economie Industrielle, $92,149-178$

MacLeod, W. B. \& J. M. Malcolmson (1998): "Motivation and Markets", American Economic Review, 88, 388-411.

MacLeod, W. B. \& D. Parent (1999), "Job Characteristics and the Form of Compensation", USC Law School, Olin Working Paper No. 99-10.

Medoff, J.L. \& K.G. Abraham (1980): "Experience, Performance, and Earnings", Quarterly Journal of Economics, 95, 703-736.

Shapiro, C. \& J. E. Stiglitz (1984): "Equilibrium Unemployment as a Worker Discipline Device", American Economic Review, 74, 433-44..

Williamson, O.E. (1975): Markets and Hierarchies: Analysis and Antitrust Implications, New York: The Free Press. 
Table 1. Cost of Effort Schedule

\begin{tabular}{ccccccccccc}
\hline \hline Effort & 1 & 2 & 3 & 4 & 5 & 6 & 7 & 8 & 9 & 10 \\
Cost of effort & 0 & 1 & 2 & 4 & 6 & 8 & 10 & 12 & 15 & 18 \\
\hline \hline
\end{tabular}


Table 2. Firm Behavior in the IC Treatment

\begin{tabular}{|c|c|c|c|}
\hline Dependent Variable: & $\begin{array}{c}(1) \\
\text { Wages }\end{array}$ & $\begin{array}{c}\text { (2) } \\
\text { Expected effort }\end{array}$ & $\begin{array}{c}\text { (3) } \\
\text { High-wage } \\
\text { offers }\end{array}$ \\
\hline Repeat offer & $\begin{array}{c}15.111 \\
{[2.253]^{* * *}}\end{array}$ & & \\
\hline Relationship duration & & $\begin{array}{c}0.309 \\
{[0.047]^{* * *}}\end{array}$ & $\begin{array}{c}0.033 \\
{[0.019]^{*}}\end{array}$ \\
\hline Wage & & $\begin{array}{c}0.112 \\
{[0.007]^{* * *}}\end{array}$ & \\
\hline Effort in prior period & & & $\begin{array}{c}0.142 \\
{[0.014]^{* * * *}}\end{array}$ \\
\hline Period & $\begin{array}{l}-0.317 \\
{[0.205]}\end{array}$ & & $\begin{array}{c}0.013 \\
{[0.004]^{* * *}}\end{array}$ \\
\hline Constant & $\begin{array}{c}41.463 \\
{[3.776]^{* * *}}\end{array}$ & $\begin{array}{c}1.402 \\
{[0.232]^{* * *}}\end{array}$ & \\
\hline Observations & 786 & 520 & 484 \\
\hline R-squared & 0.18 & 0.43 & \\
\hline Pseudo R-squared & & & 0.43 \\
\hline
\end{tabular}

Column 1 of the table reports OLS estimates of public and repeat wages offered by firms in the IC treatment. For each firm and period the highest public wage offer and the highest private wage offer to its current worker are considered. The explanatory variable Repeat offer is a dummy variable which is 1 only for private offers to the current worker. The explanatory variable Period is the period of the experiment in which an offer is made. Column 2 reports OLS estimates of the effort level which firms expect the worker to perform after a contract has been accepted. The explanatory variable Relationship duration is the number of periods which the firm and worker contracted with each other prior to the period in question. The explanatory variable Wage is the wage offered by the firm in the accepted contract. Column 3 reports probit estimates of the probability that a firm offers its current worker a high-wage contract. The coefficients reported are marginal effects calculated at the sample means. A high-wage contract is defined as a contract in which the wage exceeds the average wage paid in accepted public contracts in that period. The explanatory variable Effort in prior period is the level of effort the worker performed in the last period. All columns report standard errors in parentheses, which are adjusted for clustering within sessions. One star indicates that the estimated coefficient is significantly different from zero at $10 \%$ level; two stars at $5 \%$; three stars at $1 \%$. 
Table 3. Worker Effort in the IC and ICR

\begin{tabular}{|c|c|c|c|c|c|c|}
\hline \multirow[b]{2}{*}{ Dependent Variable: } & \multicolumn{2}{|c|}{ IC Treatment } & \multicolumn{2}{|c|}{ ICR Treatment } & \multicolumn{2}{|c|}{ IC and ICR Treatments } \\
\hline & (1) & (2) & (3) & (4) & (5) & (6) \\
\hline Wage & 0.225 & 0.262 & 0.129 & 0.122 & 0.166 & 0.178 \\
\hline & {$[0.031]^{* * *}$} & {$[0.038]^{* * *}$} & {$[0.024]^{* * *}$} & {$[0.025] * * *$} & {$[0.019] * * *$} & {$[0.022] * * *$} \\
\hline Private & 3.728 & & 0.472 & & 0.486 & \\
\hline & {$[0.729] * * *$} & & {$[0.284]^{*}$} & & {$[0.296]$} & \\
\hline Above public wage & & $\begin{array}{c}1.191 \\
{[0.620]^{*}}\end{array}$ & & $\begin{array}{c}0.338 \\
{[0.274]}\end{array}$ & & $\begin{array}{c}-0.237 \\
{[0.313]}\end{array}$ \\
\hline IC & & & & & $\begin{array}{c}-1.784 \\
{[0.595] * * *}\end{array}$ & $\begin{array}{c}-0.947 \\
{[0.623]}\end{array}$ \\
\hline IC*private & & & & & $\begin{array}{c}3.228 \\
{[0.642]^{* * *}}\end{array}$ & \\
\hline IC * Above public wage & & & & & & $\begin{array}{c}2.019 \\
{[0.602]^{* * *}}\end{array}$ \\
\hline Final periods & $\begin{array}{c}-1.658 \\
{[0.478]^{* * *}}\end{array}$ & $\begin{array}{c}-1.301 \\
{[0.466]^{* * *}}\end{array}$ & $\begin{array}{c}-0.221 \\
{[0.249]}\end{array}$ & $\begin{array}{c}-0.183 \\
{[0.247]}\end{array}$ & $\begin{array}{c}-0.857 \\
{[0.256]^{* * *}}\end{array}$ & $\begin{array}{c}-0.703 \\
{[0.247]^{* * *}}\end{array}$ \\
\hline Constant & $\begin{array}{c}-6.606 \\
{[1.741]^{* * *}} \\
\end{array}$ & $\begin{array}{c}-7.046 \\
{[1.936]^{* * *}} \\
\end{array}$ & $\begin{array}{c}-0.674 \\
{[0.832]}\end{array}$ & $\begin{array}{c}-0.398 \\
{[0.899]}\end{array}$ & $\begin{array}{c}-2.043 \\
{[0.696]^{* * *}}\end{array}$ & $\begin{array}{c}-2.269 \\
{[0.831]^{* * *}}\end{array}$ \\
\hline Observations & 520 & 520 & 523 & 523 & 1043 & 1043 \\
\hline Wald $\chi$ & 68.84 & 59.13 & 52.17 & 35.35 & 172.29 & 129.44 \\
\hline Prob. & 0.00 & 0.00 & 0.00 & 0.00 & 0.00 & 0.00 \\
\hline
\end{tabular}

The table reports censored regressions for the effort level provided by firms in the IC and ICR treatments. For each firm the effort level provided in each period is considered. The explanatory variable Wage is the wage offered by the firm in the accepted contract. The explanatory variable Private is a dummy variable which is 1 only for private offers to the current worker.

The explanatory variable Above public wage is a dummy variable for which is 1 only for contracts in which the wage exceeds the average wage paid in accepted public contracts in that period. The explanatory variable Final periods is a dummy variable which is 1 only for contracts which take place in periods $11-15$. The explanatory variable $I C$ in the pooled regressions of column 5 and 6 is a dummy variable which is 1 only for contracts in the IC treatment offers to the current worker. All columns report standard errors in parentheses, which are adjusted for clustering within sessions. One star indicates that the estimated coefficient is significantly different from zero at $10 \%$ level; two stars at $5 \%$; three stars at $1 \%$. 
Table 4. Contract Renewals in the IC and C Treatments

\begin{tabular}{cccccccccccccccc} 
& \multicolumn{11}{c}{ Period } \\
& 2 & 3 & 4 & 5 & 6 & 7 & 8 & 9 & 10 & 11 & 12 & 13 & 14 & 15 & Total \\
\hline IC & .26 & .24 & .29 & .39 & .43 & .37 & .43 & .35 & .43 & .46 & .43 & .43 & .40 & .37 & .38 \\
$\mathrm{C}$ & .12 & .11 & .12 & .12 & .09 & .03 & .14 & .06 & .03 & .21 & .06 & .09 & .09 & .14 & .10 \\
\hline \hline
\end{tabular}

The table reports the share of accepted contracts per period, which are renewed. A renewed contract is defined as a contract involving the same firm and worker as in the prior period, and which was initiated by a private offer of the firm. 
Table 5. Renewal Behavior of Firms and Workers in the IC and IC* Treatments

\begin{tabular}{lcc}
\hline \hline & $(1)$ & $(2)$ \\
\multicolumn{1}{c}{ Dependent Variable: } & Contract offered & Contract Accepted \\
\hline \multirow{2}{*}{ IC } & & \\
& 0.074 & -0.47 \\
Effort in prior period & {$[0.079]$} & {$[0.055]^{* * *}$} \\
& 0.108 & \\
Wage & {$[0.013]^{* * *}$} & 0.011 \\
& & {$[0.002]^{* * *}$} \\
Period & & 0.003 \\
& 0.016 & {$[0.005]$} \\
\hline Observations & {$[0.004]^{* * *}$} & 594 \\
Wald $\chi$ & 972 & 97.82 \\
Prob. & 183.26 & 0.00 \\
\hline \hline
\end{tabular}

Column 1 of the table reports probit estimates of the probability of firms in the IC and IC* treatments offering renewed contracts. A renewed contract offer is defined as a private offer by the firm to its current worker. Column 2 of the table reports probit estimates of the probability of a worker accepting a renewed contract in the IC and IC* treatments.

The explanatory variable $I C$ is a dummy variable, which is 1 only for contracts in the IC treatment offers to the current worker. The explanatory variable Effort in prior period is the level of effort the worker performed in the last period. The explanatory variable "Wage" is the wage offered by the firm in the accepted contract. The explanatory variable Period is the period of the experiment in which an offer is made. In both columns reported estimates are marginal effects, calculated at the sample mean. All columns report standard errors in parentheses, which are adjusted for clustering within sessions. One star indicates that the estimated coefficient is significantly different from zero at $10 \%$ level; two stars at $5 \%$; three stars at $1 \%$. 
Table 6. Relation duration, wages and effort in IC and IC*

\begin{tabular}{clcccc}
\hline \hline & & \multicolumn{4}{c}{ Relationship duration in periods } \\
& & 1 & $2-5$ & $6-10$ & $11-15$ \\
\hline \multirow{2}{*}{ IC } & Effort & 4.7 & 7.4 & 8.9 & 9.9 \\
& Wage & 50.6 & 54.8 & 60.1 & 60.4 \\
\hline \multirow{2}{*}{ IC $^{*}$} & Effort & 4.3 & 6.2 & 8.4 & 9.4 \\
& Wage & 26.8 & 34.7 & 46.7 & 54.4 \\
\hline \hline
\end{tabular}

The table reports mean effort levels of firms and wages paid by firms for trades, which take place in relationships of varying final durations. 
Figure 1. Wage offers in the IC and $\mathrm{C}$ treatments

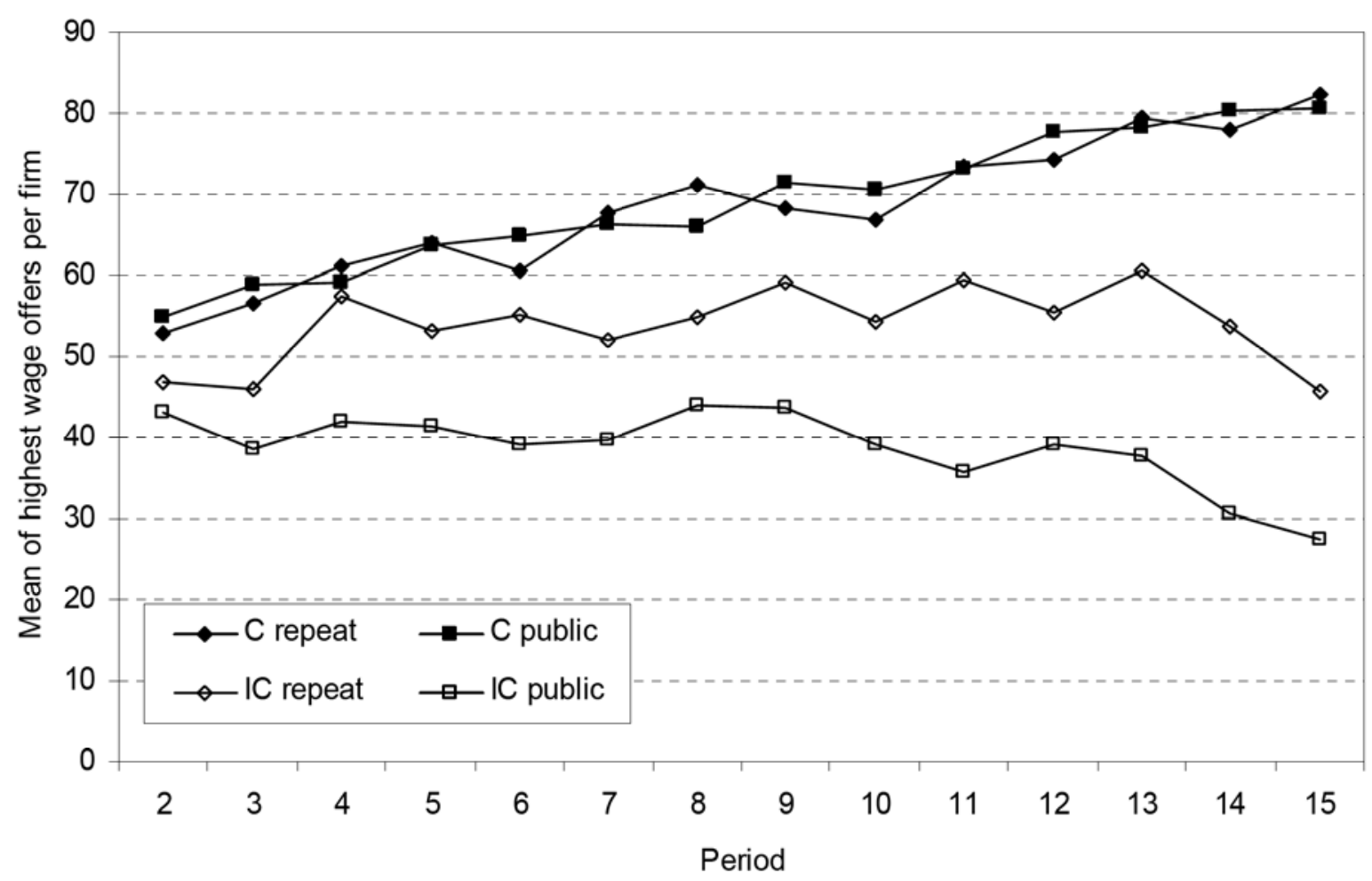


Figure 2. Frequency of Effort Levels in the IC and ICR treatments

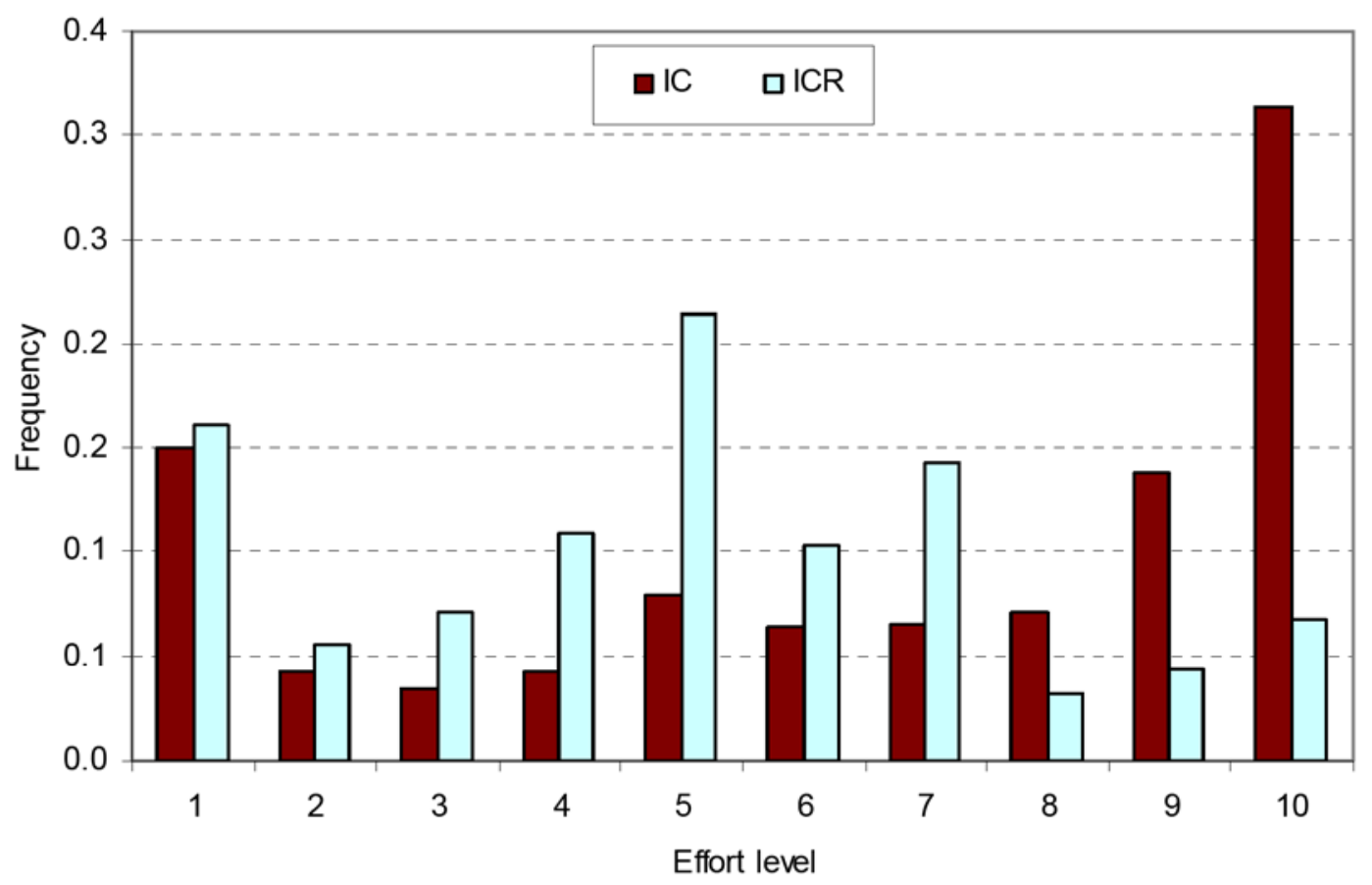


Figure 3. Market Conditions and Relations

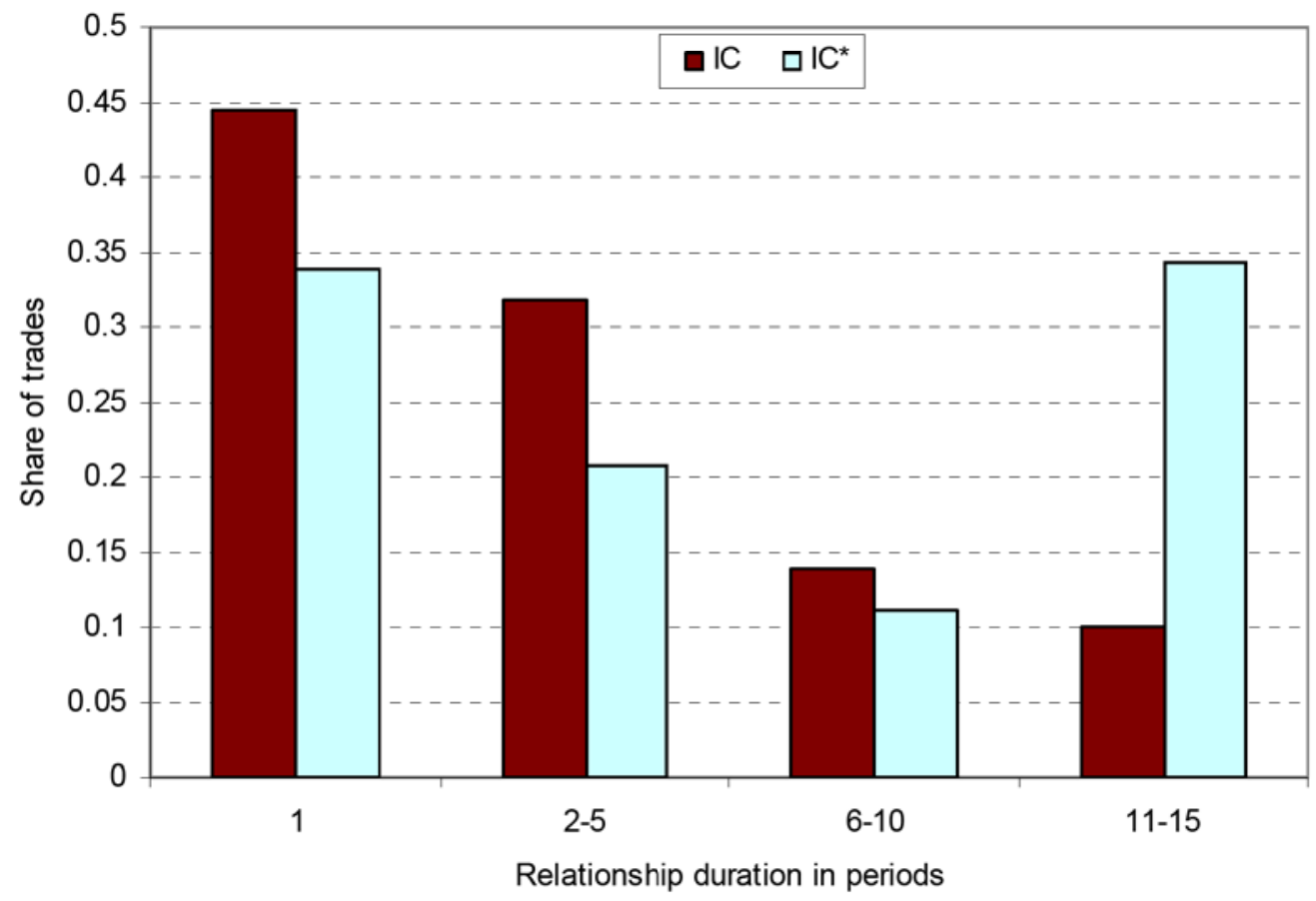


Figure 4. Competition and Market Performance

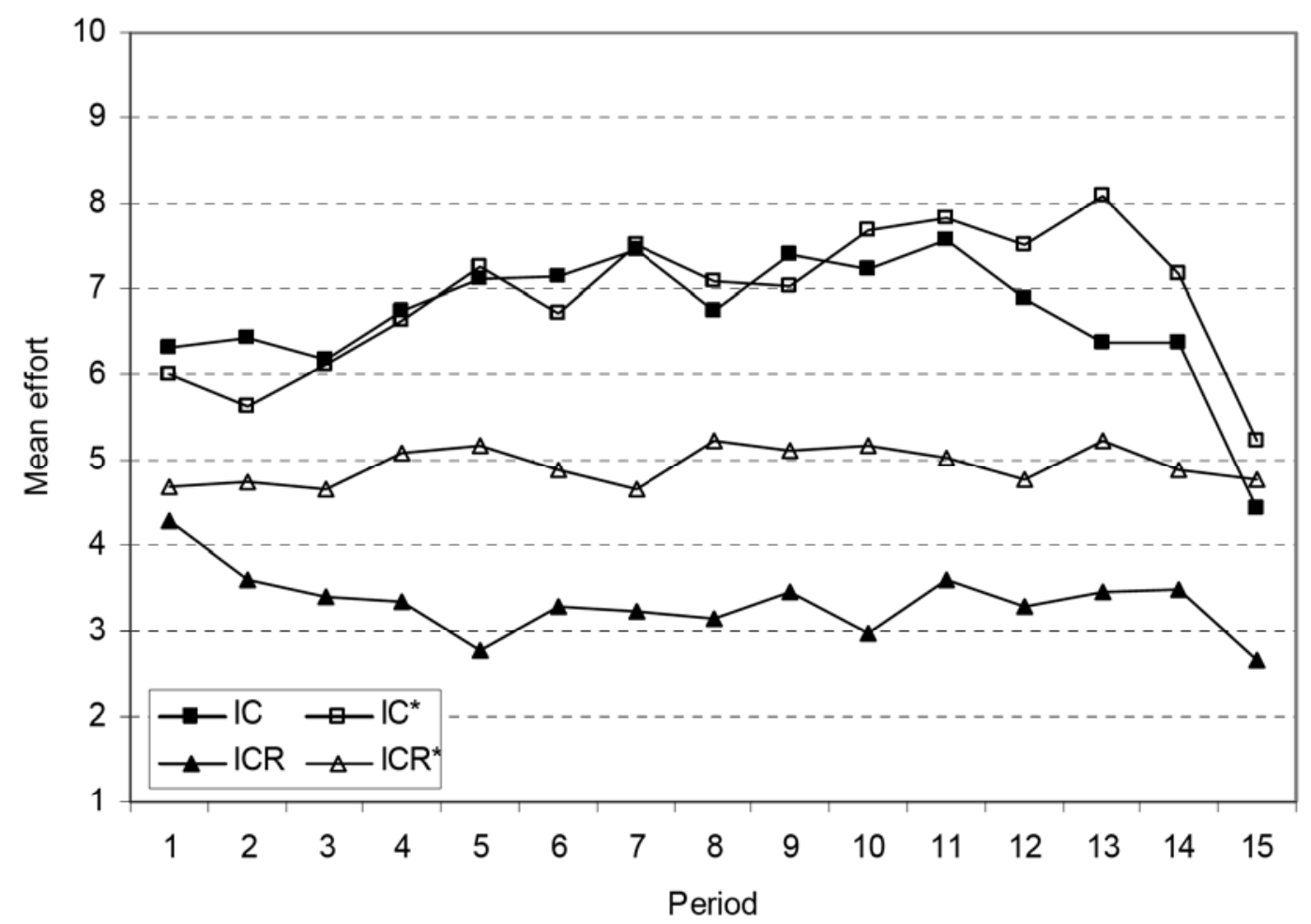




\section{Appendix A. Predictions}

The gift-exchange game analyzed in this appendix corresponds to that of our experiment:

- A firm offers a contract $[w, \tilde{e}]$ to a worker. A contract stipulates a non-negative wage offer $w \in[0,100]$. The contract also states the desired effort level of the firm $\tilde{e} \in[1,10]$.

- The worker decides whether to accept or reject the offer.

- If the worker accepts the contract he chooses an actual effort level $e \in[1,10]$, which must not (but can) coincide with the firms desired effort $\tilde{e}$.

At the end of each period the firm earns monetary payoffs of:

$[A 1] \pi(w, e)=\left\{\begin{array}{cc}10 e-w & \text { if the contract offer is accepted } \\ 0 & \text { otherwise }\end{array}\right.$

The worker earns monetary payoffs per period of:

$[A 2] v(w, e)=\left\{\begin{array}{cc}w-c(e) & \text { if a contract is accepted } \\ 5 & \text { otherwise }\end{array}\right.$

The cost of effort to the worker $c(e)$ is given by

$[A 3]$

\begin{tabular}{|l|l|l|l|l|l|l|l|l|l|l|}
\hline$e$ & 1 & 2 & 3 & 4 & 5 & 6 & 7 & 8 & 9 & 10 \\
\hline$c(e)$ & 0 & 1 & 2 & 4 & 6 & 8 & 10 & 12 & 15 & 18 \\
\hline
\end{tabular}

We assume that workers are drawn from a population in which some have "fair" preferences that incline them to provide non-minimal effort even in a one-shot situation. We assume that with probability $p \in(0,1)$ a worker is fair. The utility of a fair worker in any period $t$ is given by:

$[A 4] u(w, e, \tilde{e})=\left\{\begin{array}{cl}v(w, e) & \text { if } w-c(\tilde{e})<10 \tilde{e}-w \\ v(w, e)-b \max [\tilde{e}-e ; 0] & \text { if } w-c(\tilde{e}) \geq 10 \tilde{e}-w\end{array}\right.$

We assume that a fair worker has a bad conscience if he does not fulfill a contract which offers him (at least) payoff sharing contract terms. We assume that the marginal disutility of not fulfilling a fair contract is always higher than the marginal cost of effort $(b>3)$ so that a fair worker will always adhere to any contract which offers him at least payoff sharing terms. If the firm offers "unfair" contract terms a fair worker does not suffer from a bad conscience if he shirks.

From $[A 4]$ we can deduct that in order to motivate a fair worker to perform any desired effort $\tilde{e}>1$, a firm must offer at least the payoff-sharing wage $\hat{w}(\tilde{e})=5 \tilde{e}+\frac{1}{2} c(\tilde{e})$ :

$[A 5]$

\begin{tabular}{|l|l|l|l|l|l|l|l|l|l|}
\hline$\tilde{e}$ & 2 & 3 & 4 & 5 & 6 & 7 & 8 & 9 & 10 \\
\hline$\hat{w}(\tilde{e})$ & 12 & 16 & 22 & 28 & 34 & 40 & 46 & 53 & 59 \\
\hline
\end{tabular}

\section{One Period Game (ICR Treatment)}

In our ICR treatment the ID numbers of all participants are assigned freshly in each period. This treatments can therefore be analyzed as a series of one-period games.

In a one period game a firm knows that if its contract is accepted by a selfish worker he will always perform minimal effort $e=1$. A firm knows that with a probability $1-p$ each worker is selfish. A firm also knows that with probability $p$ each worker is fair. If a fair worker accepts a contract he will perform $e=\tilde{e}$ if he receives a payoff-sharing contract, i.e. $w \geq \hat{w}(\tilde{e})$. If however he receives a contract with $w<\hat{w}(\tilde{e})$ he will perform the minimal effort $e=1$. In the one period game the expected profit of a firm from an accepted contract is thus given by 
$[A 6] \pi^{e}(w, \tilde{e})=\left\{\begin{array}{cl}p 10 \tilde{e}+(1-p) 10-w & \text { if } w \geq \hat{w}(\tilde{e}) \\ 10-w & \text { if } w<\hat{w}(\tilde{e})\end{array}\right.$

We now consider a one-period game with an excess demand for labor, which resembles our ICR treatment. We assume simplified trading procedures in order to ensure tractability: Suppose that there are $n>2$ players of which $n-1$ are firms, but only 1 is a worker. The $n-1$ firms simultaneously make one contract offer $[w, \tilde{e}]$ each. After being informed about all offers the worker chooses his preferred one and then chooses a feasible effort level.

Proposition A1: Consider a game of $T=1$ period with of $n>1$ firms and 1 worker who is fair with probability $p \in(0,1)$. If $p<0.2$ there exists no perfect Bayesian equilibrium in which a worker performs $e>1$. If $p \geq .544$ there exists a perfect Bayesian equilibrium in which a fair worker performs maximum effort $e=10$ while a selfish worker performs $e=1$.

Proof of Proposition A1: With an excess demand for workers, competition will force firms to offer the contract which provides workers with the maximum payoff under the condition that firms make non-negative expected profits. Equilibrium contracts of firms $\left[w^{*}, \tilde{e}^{*}\right]$ will thus be characterised by $\pi^{e}\left(w^{*}, \tilde{e}^{*}\right)=0$ or

$[A 7] w^{*}(p, \tilde{e})=p 10 \tilde{e}+(1-p) 10$.

Fair workers earn $v^{\text {fair }}\left(w^{*}, \tilde{e}^{*}\right)=w^{*}\left(p, \tilde{e}^{*}\right)-c\left(\tilde{e}^{*}\right)$, and therefore strictly prefer contracts with higher demanded effort $\tilde{e}$ (and corresponding wages) if

$[A 8] p>\frac{1}{10} \frac{\partial c(e)}{\partial e}$

Selfish workers earn $v^{\text {selfish }}\left(w^{*}, \tilde{e}^{*}\right)=w^{*}\left(p, \tilde{e}^{*}\right)$ and thus always strictly prefer contracts with higher demanded effort $\tilde{e}$ and corresponding wages $w^{*}(p, \tilde{e})$.

From $[A 7]$ and $[A 6]$ we see that firms can only profitably offer a payoff sharing contract with $\tilde{e}>1$ if $w^{*}(p, \tilde{e}) \geq \hat{w}(\tilde{e})$. This requires a minimal share of fair workers

$[A 9] \hat{p}(\tilde{e}) \geq \frac{\hat{w}(\tilde{e})-10}{10(\tilde{e}-1)}$

From $[A 9]$ and $[A 5]$ we can calculate the minimal share of fair workers $\hat{p}$, required so that a firm can offer a payoff-sharing contract demanding non-minimal effort levels, without making losses:

\begin{tabular}{|l|l|l|l|l|l|l|l|l|l|}
\hline$\tilde{e}$ & 2 & 3 & 4 & 5 & 6 & 7 & 8 & 9 & 10 \\
\hline$\hat{p}(\tilde{e})$ & .2 & .3 & .4 & .45 & .48 & .5 & .514 & .538 & .544 \\
\hline
\end{tabular}

From the table we see that if $p<.2$ firms cannot profitably offer any contract which demands $\tilde{e}>1$. In this case all firms will offer the contract $\left[w^{*}, \tilde{e}^{*}\right]=[10,1]$. As the share of fair workers rises firms can profitably offer contracts which demand non-minimal effort. Moreover, comparing $[A 8]$ and $[A 9]$ we see that if the share of fair workers is sufficient for firms to demand $\tilde{e}>1$, fair workers will strictly prefer the contract with the maximum feasible effort level. Thus competition will lead firms to offer contracts which demand the highest effort level which yields non-negative profits given $p$, and offering wages so that firms earn zero profits $w^{*}(p, \tilde{e})=p 10 \tilde{e}+(1-p) 10$. The table above shows that if $p \geq .544$ firms can profitably offer payoff sharing contracts which demand maximum effort. This concludes our proof of Proposition A1.

\section{Multi-Period Games}

We now derive predictions for mutli-period games which resemble our IC treatment and the IC* treatment. Assuming the presence of some (non-identifiable) fair workers these treatments can be characterized as repeated games of incomplete information. In such games there exist mutliple 
perfect Bayesian equilibria, supported by different on-equilibrium and off-equilibrium beliefs. We do not attempt to characzterize all potential equilibria. Instead we demonstrate that there exist equilibria in which relational contracts between firms and workers sustain maximum effort of both fair and selfish workers in all non-final periods.

Assume that it is common knowledge that $p=.6+\varepsilon$, where $\varepsilon$ is a small number. From Proposition A1 we know that in the one period game maximum effort is demanded under an excess demand for labor $\left(\tilde{e}^{*}=10\right)$ and that expected effort in the one-period equilibrium is $p \tilde{e}^{*}=6$.

\section{Excess Demand for Labour (IC Treatment)}

We first consider a multi-period game with an excess demand for labor, which resembles our IC treatment. Again, we assume simplified trading procedures in order to ensure tractability. We suppose that there are $n>2$ players of which $n-1$ are firms and 1 is a worker. The $n-1$ firms simultaneously make one contract offer each. After being informed about all offers the worker chooses his preferred one and then chooses a feasible effort level.

Proposition A2: Consider a game of $T>1$ periods with $n-1>1$ firms and 1 worker who is fair with probability $p=.6+\varepsilon$. The following strategies and beliefs constitute a perfect Bayesian equilibrium in which both worker types perform maximum effort in all non-final periods $t<T$ :

- All firms offer the identical contract $\left[w_{1}^{*}, \tilde{e}_{1}^{*}\right]=[100,10]$ in period 1 .

- In all periods $1<t<T$ the incumbent firm offers the payoff splitting contract $\left[w_{t}^{i n c}, \tilde{e}_{t}^{i n c}\right]=$ $[59,10]$ if the worker performed the demanded effort in all previous periods. If the worker ever shirked the firm offers the contract $\left[w_{t}, \tilde{e}_{t}\right]=[10,1]$ in all future periods. In period $T$ the incumbent firm offers the payoff splitting contract $\left[w_{T}^{i n c}, \tilde{e}_{T}^{i n c}\right]=[46,8]$ if the worker performed the demanded effort in all previous periods. If the worker ever shirked the firm offers the contract $\left[w_{T}, \tilde{e}_{T}\right]=[10,1]$ in period $T$.

- In all periods $t>1$ "outside" firms (those who didn't trade in period $t-1$ ) offer the contract $\left[w_{t}^{\text {out }}, \tilde{e}_{t}^{\text {out }}\right]=[10,1]$.

- In period 1 the worker selects one of the available contracts and performs the desired maximum effort $e_{t}=10$ if he is selfish or fair. In period $1<t<T$ the worker accepts the contract of his incumbent firm and performs maximum effort if he is fair or selfish. In the final period the worker again accepts the contract of the incumbent firm. If he is selfish he performs $e_{T}=1$. If he is fair he performs $e_{T}=10$.

- (Out of Equilibrium beliefs): The incumbent firm believes that if the worker ever shirks he is selfish. Outside firms believe that if the worker switches firms in any period $t>1$ he is fair with a probability of $p \leq .2$ and will switch again in the following period.

Proof of Proposition A2: We prove Proposition A2 in five steps:

Step 1 (behavior of a fair worker): A fair worker will perform the desired effort $\tilde{e}_{t}=10$ in any period $t$ if and only if this contract offers at least equal splitting of earnings $w_{t}^{*} \geq \hat{w}\left(\tilde{e}_{t}\right)$. From the contracts offered in period 1 by all firms and by the incumbent firm in periods $t>1$ we see that this is always the case. Moreover, as outside firms offer only the contract $[10,1]$ it is the best response for the worker to always accept the contract of the incumbent firm in all periods $t>1$.

Step 2 (behavior of a selfish worker): In the final period $T$ a selfish worker will accept the contract which offers the highest wage and will perform $e_{T}^{*}=1$. If the selfish worker performed in all prior periods it is a unique best strategy of the selfish worker to accept the contract of the incumbent firm $\left[w_{T}^{i n c}, \tilde{e}_{T}^{i n c}\right]$. Consider now the effort choice of a selfish worker in any period $t<T$. If he shirks he will get the contract $\left[w_{t}, \tilde{e}_{t}\right]=[10,1]$ and earn 10 in all future periods $k>t$. If he performs the desired effort of his incumbent firm he incurs the costs for the demanded effort 
$c\left(\tilde{e}_{t}^{*}\right)=18$, but receives a repeat contract in period $t+1$ where he expects a wage $w_{t+1}^{\text {inc }}$. A selfish worker will perform the maximum effort $e_{t}=10$ in any non final period $t<T$ if the following incentive constraint is met:

$[A 11] c\left(\tilde{e}_{t}^{*}\right)+\sum_{k=t+1}^{T-1}\left[w_{k}^{i n c}-c\left(\tilde{e}_{k}^{i n c}\right)\right]+w_{T}^{i n c} \geq(T-t) 10$

The participation constraint of a selfish worker in any period $t<T$ is given by:

$[A 12] \sum_{k=t}^{T-1}\left[w_{k}^{i n c}-c\left(\tilde{e}_{k}^{i n c}\right)\right]+w_{T}^{i n c} \geq(T-t+1) 10$

As $\left[w_{k}^{i n c}, \tilde{e}_{k}^{i n c}\right]=[59,10]$ all $1<k<T$ and $\left[w_{T}^{i n c}, \tilde{e}_{T}^{i n c}\right]=[46,8]$ conditions $[A 11]$ and $[A 12]$ are always met with inequality. It is therefore the best strategy of the selfish worker to perform $e_{t}=10$ in any period $t<T$.

Step 3 (Contract of the incumbent firm in periods $t>1$ ):

Given that outside firms only offer the contract $\left[w_{t}, \tilde{e}_{t}\right]=[10,1]$ the incumbent firm is not under competition for a performing worker. It can therefore choose a contract to maximize profits. In any period $t<T$ both worker types perform $e_{t}=\tilde{e}_{t}$ as long as $w_{t}^{*} \geq \hat{w}\left(\tilde{e}_{t}\right)$. As a consequence it is profit maximizing for the firm to offer the contract $\left[w_{t}^{i n c}, \tilde{e}_{t}^{i n c}\right]=[59,10]$ which generates maximum effort and just offers the worker an equal share of earnings.

In period $T$ the incumbent firm knows that only a fair worker will adhere to a contract. In equilibrium the firm gains no information from the behavior of the worker in any period $t<T$ because it is the best strategy of both worker types to perform. Given the rational belief $p=.6+\varepsilon$ and the absence of competition from outside firms it is profit maximizing to offer the contract $\left[w_{T}^{i n c}, \tilde{e}_{T}^{i n c}\right]=[46,8]$. This can be seen by maximizing $[A 6]$ given the constraint on firms that they must offer $\hat{w}(\tilde{e})=5 \tilde{e}+\frac{1}{2} c(\tilde{e})$ in order to motivate non-minimal effort from fair workers.

The out of equilibrium belief that a shirker is selfish (and competition from outside firms) makes it optimal to offer the contract $\left[w_{t}, \tilde{e}_{t}\right]=[10,1]$ to the worker if he shirked in the past.

Step 4 (Contracts of "outside" firms in periods $\mathbf{t}>1$ ): Outside firms believe that if the worker switches firms in any period $t<1$ he is fair with a probability of $p^{\text {out }}<.2$. They also believe that the worker will switch again in the following period so that they would be playing a one-period game if the contract was accepted. From Proposition A1 we know that given the belief $p^{\text {out }}$ an outside firm cannot profitably offer a contract with non-minimal effort. Given the competition for workers it is then the best strategy for outside firms to offer $\left[w_{t}, \tilde{e}_{t}\right]=[10,1]$.

Step 5: (contracts of firms in period 1): In periods $t>1$ the incumbent firm earns substantial rents. Thus in period 1 firms compete strongly to become the incumbent firm. In all periods $1<t<T$ they earn a profit of $100-59=41$. In period $T$ they earn an expected profit of $48+4-46=6+\varepsilon$. In period 1 firms will therefore bid each other up to the highest wage which generates zero expected future profits, or the maximum feasible wage in our experiment of $w=100$. The expected profits are given by:

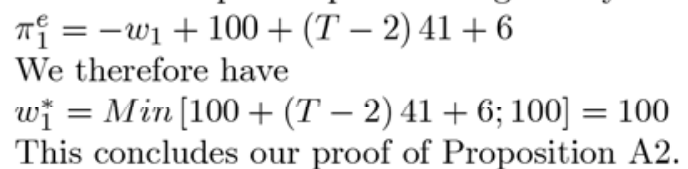

\section{Excess Supply of Labour (IC* Treatment)}

We now consider a multi-period game with an excess supply of labor, which resembles our IC* treatment. Again, we assume simplified trading procedures in order to ensure tractability. Suppose that there are $n>2$ players of which $n-1$ are workers, but only 1 is a firm. We assume that in each period the firm makes a contract to one of the workers. Only this worker is informed about the offer and he then chooses whether to accept the contract. 
Proposition A3: Consider a game of $T>1$ periods with 1 firm and $n-1>1$ workers who are fair with probability $p=.6+\varepsilon$. The following strategies and beliefs constitute a perfect Bayesian equilibrium in which both worker types perform maximum effort in all non-final periods $t<T$ :

- The firm offers the contract $\left[w_{1}^{*}, \tilde{e}_{1}^{*}\right]=[59,10]$ to a randomly chosen worker in period 1 .

- In all periods $1<t<T$ the firm offers the contract $\left[w_{t}^{*}, \tilde{e}_{t}^{*}\right]=[59,10]$ to his incumbent worker, if the worker performed $e_{t-1}=10$. If the incumbent worker performed $e_{t-1}<10$ the firm offers the contract $\left[w_{t}^{*}, \tilde{e}_{t}^{*}\right]=[59,10]$ to one of the workers he has not yet traded with. If $e_{t-1}<1$ and he has traded with all workers, the firm offers the contract $\left[w_{t}^{*}, \tilde{e}_{t}^{*}\right]=[5,1]$ to any worker.

- In period $T$ the firm offers the contract $\left[w_{T}^{*}, \tilde{e}_{T}^{*}\right]=[46,8]$ to his incumbent worker, if the worker performed $e_{T-1}=10$. If the incumbent worker performed $e_{T-1}<10$ the firm offers the contract $\left[w_{T}^{*}, \tilde{e}_{T}^{*}\right]=[46,8]$ to one of the workers he has not yet traded with. If $e_{T-1}<10$ and he has traded with all workers, the firm offers the contract $\left[w_{t}^{*}, \tilde{e}_{t}^{*}\right]=[5,1]$ to a randomly chosen worker.

- In all periods $t$ a fair worker accepts a contract and performs $e_{t}=\tilde{e}_{t}$.

- In all periods $t<T$ a selfish worker accepts a contract and performs $e_{t}=10$. In the final period a selfish worker accepts a contract and performs $e_{T}=1$.

- (Out of Equilibrium beliefs): The firm believes that any worker who shirks in any non-final period is selfish.

Proof of Proposition A3: We prove Proposition A3 in three steps:

Step 1 (behavior of a fair worker): In all periods the firm offers a contract $\left[w_{t}^{*}, \tilde{e}_{t}^{*}\right]$ with $w_{t}^{*}=\hat{w}\left(\tilde{e}_{t}^{*}\right)$. It is a best response for a fair worker to always accept and adhere to this contract as $w_{t}^{*}-c\left(\tilde{e}_{t}^{*}\right)>5$ and $w_{t}^{*}=\hat{w}\left(\tilde{e}_{t}^{*}\right)$.

Step 2 (behavior of a selfish worker): From Proposition A1 we know that in the final period $T$ a selfish worker will accept the contract if $w_{T}^{*}>5$ and will perform $e_{T}^{*}=1$. As $w_{T}^{*}>5$ it is a unique best strategy of the selfish worker to accept this contract.

Consider now the effort choice of a selfish worker in any period $t<T$. If he shirks he will earn an income of 5 in all future periods $k>t$. If he performs the desired effort of the firm he incurs the costs for the demanded effort $c\left(\tilde{e}_{t}^{*}\right)$, but receives a repeat contract $\left[w_{t+1}^{*}, \tilde{e}_{t+1}^{*}\right]$ in period $t+1$. A selfish worker will perform the maximum effort $e_{t}=10$ in any non final period $t<T$ if the following incentive constraint is met:

$[A 13]-c\left(\tilde{e}_{t}^{*}\right)+\sum_{k=t+1}^{T-1}\left[w_{k}^{*}-c\left(\tilde{e}_{k}^{*}\right)\right]+w_{T}^{*} \geq(T-t) 5$

His participation constraint in any period $t<T$ is given by:

$[A 14] \sum_{k=t}^{T-1}\left[w_{k}^{*}-c\left(\tilde{e}_{k}^{*}\right)\right]+w_{T}^{*} \geq(T-t+1) 5$

As $\left[w_{k}^{*}, \tilde{e}_{k}^{*}\right]=[59,10]$ all $k<T$ and $\left[w_{T}^{*}, \tilde{e}_{T}^{*}\right]=[46,8]$ conditions $[A 13]$ and $[A 14]$ are met with inequality in any period $t<T$.

Step 3 (Contracts of the firm): In equilibrium the firm learns nothing from the behavior of workers in periods $t<T$ as it is optimal for both worker types to perform. As the firm is not under competition for labor it can choose the profit maximizing contract in each period. Given the effort strategy of the workers the firm knows that fair workers will perform its desired effort as long as $w_{t}^{*}>\hat{w}\left(\tilde{e}_{t}^{*}\right)$ all $t<T$. Moreover, while the incentive constraint of a selfish worker only depends on future contract promises, a selfish worker would also perform in period $t$ only if 
$w_{t}^{*}<\hat{w}\left(\tilde{e}_{t}^{*}\right)$ because he imitates fair workers. If both workers do respond to a fair contract with the desired effort then the profit maximizing contract offer is $\left[w_{t}^{*}, \tilde{e}_{t}^{*}\right]=[59,10]$.

In period $T$ the firm knows that only a fair worker will perform its desired effort. Due to the pooling behavior of workers in equilibrium the rational belief of the firm in period $T$ is $p=.6+\varepsilon$. We know from Proposition A2 that the profit maximizing contract offer of the firm in this case is $\left[w_{T}^{*}, \tilde{e}_{T}^{*}\right]=[46,8]$

Given its out of equilibrium belief that only selfish workers shirk in non-final periods, it is optimal for the firm to fire a shirker and hire a new worker in his place. If all workers have shirked the firm believes that all are selfish. In this case it is optimal to offer $\left[w^{*}, \tilde{e}^{*}\right]=[5,1]$ to any worker in all future periods.

This concludes our proof of Proposition A3. 


\section{Appendix B. Instructions}

The following instructions are translations of the original German instructions for buyers and sellers in our IC treatment. The instructions for the ICR treatment are identical to those displayed, except that it is explicitly stated that identification numbers of buyers and sellers are randomly assigned in each period. The instructions for the $\mathrm{C}$ treatment are identical to those displayed, except that it is explicitly stated that sellers must provide the quality desired by buyers. The original instructions for all three treatments are available (in German) from the authors. 


\section{Instructions for Buyers}

You are now taking part in an economic experiment. Please read the following instructions carefully. Everything that you need to know to participate in this experiment is explained below. Should you have any difficulties in understanding these instructions please notify us. We will answer your questions at your cubicle.

At the beginning of the experiment you will receive an initial sum of 10 Swiss Francs. During the course of the experiment you can earn a further amount of money by gaining points. The amount of points that you gain during the experiment depends on your decisions and the decisions of other participants.

All points that you gain during the course of the experiment will be exchanged into Swiss Francs at the end of the experiment. The exchange rate will be:

1 point $=0.10$ Swiss Francs

At the end of the experiment you will receive the sum of money that you earned during the experiment in addition to your 10 Francs initial sum.

The experiment is divided into periods. In each period you have to make decisions which you will enter in a computer. There are 15 periods in all.

Please note that communication between participants is strictly prohibited during the experiment. In addition we would like to point out that you may only use the computer functions which are required for the experiment. Communication between participants and unnecessary interference with computers will lead to exclusion from the experiment. In case you have any questions we shall be glad to assist you.

Prior to the experiment the 17 participants were divided into 2 groups: buyers and sellers. In this experiment there are 10 buyers and 7 sellers.

You shall be a buyer for the entire course of the experiment. All participants have received an identification number which they will keep for the entire experiment. Your identification number is stated on the documentation sheet in front of you.

\section{An Overview of the Experiment Procedures}

In each period of the experiment every buyer can trade a product with one seller. The seller earns a profit through the trade when he sells the product at a price which exceeds his production costs. The buyer earns a profit through the trade when the price he pays for the product is less than what it is worth to him. How high the production costs are for the traded product and how much it is worth to the buyer depends on the quality of the product.

The experiment lasts 15 periods. In each period the procedures are as follows:

1. Each period commences with a trading phase which lasts 3 minutes. During this phase buyers can submit trade offers which can be accepted by sellers. When submitting an offer a buyer has to specify three things:

- Which price he offers to pay,

- which product quality he desires,

- and finally, which seller he wants to submit the offer to. Hereby, buyers can submit two types of offers; private offers and public offers. Private offers are submitted to one seller only and can only be accepted by that seller. Public offers are submitted to all sellers and can be accepted by any seller. 
As a buyer you can submit as many offers as you like in each period. Submitted offers can be accepted constantly. Each buyer and each seller can only enter one trade agreement in each period. As there are 10 buyers and 7 sellers, several buyers will not trade in each period.

2. Following the trading phase each seller who has entered a trade agreement then determines which quality of product he will supply to his buyer. Hereby, the seller is not obliged to supply the product quality desired by his buyer. Once every seller has chosen which product quality to supply the points gained by each participant in that period have been determined. After this the next period commences.

The points gained from all 15 periods will be summed up at the end of the experiment, exchanged into Swiss Francs and paid together with your initial sum of money in cash.

\section{The Experiment Procedures in Detail}

There are 10 buyers and 7 sellers in the experiment. You are a buyer for the entire course of the experiment. During the experiment you will enter your discussions in a computer. In the following we describe in detail how you can make your decisions in each period.

\section{The Trading Phase}

Each period commences with a trading phase. During the trading phase each buyer can enter into a trading agreement with one seller. In order to do this each buyer can submit as many trade offers as he wishes. In each trading phase you will see the following screen:

\begin{tabular}{|c|c|c|c|c|c|c|c|c|c|c|c|c|}
\hline Period: & & & & & & $\mathrm{em}$ & ling & ime & sect & & & \\
\hline & blic off & & yot & private & & & ID & $\mathrm{Im}$ & & & & \\
\hline buyer & price & des. Q. & price & des. Q. & seller & & & & & & & \\
\hline & & & & & & & & & & & & \\
\hline & & & & & & & & & ke a & offe & & \\
\hline & & & & & & & & & & & & \\
\hline & & & & & & & & & & & & \\
\hline & & & & & & & & & & & & \\
\hline & & & & & & & & & & & & \\
\hline & & & & & & & & & whi & selle & & \\
\hline & & & & & & & & & & & & \\
\hline & & & & & & & Pri & & & & & \\
\hline & & & & & & & red & & & & & \\
\hline & & & & & & & & & & & & \\
\hline & & & & & & & & & O & & & \\
\hline & & & & & & & & & & & & \\
\hline & & & & & & 1 & 2 & 3 & 4 & 5 & 6 & 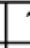 \\
\hline & & & & & & & & & & & & \\
\hline & & & & & & & & & & & & \\
\hline & & & & & & $\mathrm{Se}$ & & & & & Des. & \\
\hline & & & & & & & & & & & & \\
\hline
\end{tabular}

- In the top left corner of the screen you will see in which period the experiment is. In the top right corner of the screen you will see the time remaining in this trading phase, displayed in seconds. The trading phase in each period lasts 3 minutes (= 180 seconds). When this time is up the trading phase is over. Hereafter, no further offers can be submitted or accepted for this period. 
- Once you see the above screen displayed the trading phase commences. As a buyer you now have the opportunity to submit trade offers to the sellers. In order to do so you have to enter three things on the right hand side of the screen:

a) First you have to specify whether you want to submit a public or private offer:

\section{- Public trade offers}

Public offers will be communicated to all participants in the market. All sellers see all public offers on their screens. A public offer can therefore be accepted by any seller. As a buyer you will also see all public offers submitted by all buyers.

If you want to submit a public offer, click on the field ,public“, using the mouse.

\section{- Private trade offers}

Private offers are submitted to one seller only. Only this seller shall be informed of this offer and only this seller can accept that trade offer. No other seller or buyer will be informed of that offer.

If you want to submit a private offer, click in the field „private“ using the mouse. After that you specify which seller you want to submit the offer to in the field below. Each of the 7 sellers has an identification number (seller 1, seller 2, ....., seller 7) Each seller keeps his identification number for the entire course of the experiment. To submit an offer to a specific seller you enter the number of that seller (e.g. „4" for seller 4)

b) Once you have specified who you want to submit an offer to, you must determine which price you offer. You enter this in the field „your price“. Hereby, the price you offer can not be below 0 or above 100 .

\section{$0 \leq$ price offered $\leq \mathbf{1 0 0}$}

c) Finally you have to specify which product quality you desire. You enter this in the field „desired quality“. Your desired quality cannot be lower than 1 or higher than 10.

\section{$\mathbf{1} \leq$ desired quality $\leq \mathbf{1 0}$}

After you have completely specified your trade offer, you must click on the „ok“ button to submit it. As long as you have not clicked „ok“ you can change your trade offer. After you click „ok" the offer will be displayed to all sellers you have submitted it to.

- On the left side of your screen you will see a title „public offers“. All public offers in the current trading phase are displayed here. Your public offers as well as those of all other buyers will be displayed. You can see which buyer submitted the offer, which price he offered and which quality he desired. All buyers also have and identification number which they keep for the whole course of the experiment.

- In the middle of your screen under the title ,your private offers“ you will see all private offers, which you have submitted in the current trading phase. Here you can see which seller you submitted an offer to, which price you offered and which quality you desired.

- Each buyer can submit as many private and public offers as he wishes in each period. Each offer that you submit can be accepted at any time during the trading phase.

- Each buyer can enter only one trade agreement in each period. Once one of your offers has been accepted you will be notified which seller accepted which of your offers. In the bottom right corner of your screen the identification number of the seller will be displayed as well as your offered price and desired quality. As you can enter only one trade agreement in each period all your other offers will be automatically cancelled. Also, you will not be able to submit any further offers.

- No seller can enter more than one trade agreement in each period. You will be constantly informed which sellers have not yet accepted a trade offer. Under the title „sellers who have

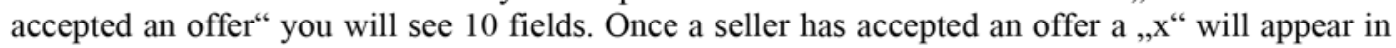


the field next to his identification number. You cannot submit private offers to a seller who has already entered a trade agreement.

- Once all 7 sellers have entered a trade agreement or after 3 minutes have eluded, the trading phase is over.

- No buyer is obliged to submit trade offers, and no seller is obliged to accept a trade offer.

\section{Determination of the Product Quality}

- Following the trading phase, all sellers who have entered a trade-agreement then determine which product quality they will supply to their respective buyers. The product quality which you desired in your trade offer is not binding for your seller. Your seller can choose the exact quality you desired, but he can also choose a higher or lower product quality. The product quality which your seller chooses has to be between 1 and 10 .

\section{$1 \leq$ product quality $\leq \mathbf{1 0}$}

- While your seller determines the actual product quality, we ask you to specify which quality you expect him to supply on a separate screen. In addition we ask you to state how sure you are of this expectation.

\section{How are the incomes calculated?}

\section{Your income:}

- If you do not enter a trade agreement during a trading phase you gain an income of 0 points for that period.

- If one of your trade offers is accepted, your income depends on which price you offered and which product quality your seller supplied to you. Your income will be determined as follows:

\section{Your income $=10 *$ product quality - price}

- As you can see from the above formula your income is higher, the higher the product quality actually supplied by your seller. At the same time your income is higher, the lower the price you paid for the product.

\section{Income of your seller}

- If a seller has not entered a trade agreement during a trading phase he gains an income of 5 point for that period.

- If a seller has accepted a trade offer his income will equal the price he receives minus the production costs he incurs for the product supplied. The income of the seller is determined as follows:

\section{Income of your seller $=$ Price - production costs}

- The production costs of a seller are higher, the higher the quality of the product he chooses. The production costs for each product quality are displayed in the table below:

\begin{tabular}{|l|l|l|l|l|l|l|l|l|l|l|}
\hline Product quality & 1 & 2 & 3 & 4 & 5 & 6 & 7 & 8 & 9 & 10 \\
\hline Production costs & 0 & 1 & 2 & 4 & 6 & 8 & 10 & 12 & 15 & 18 \\
\hline
\end{tabular}


- The income of your seller is higher, the higher the price which her accepted. Further, his income is higher, the lower the product quality he supplies to you.

The income of all buyers and sellers are determined in the same way. Each buyer can therefore calculate the income of his seller and each seller can calculate the income of his buyer. Further, each buyer and seller is informed of the identification number of his trading partner in each period.

Please note that buyers and sellers can incur losses in each period. These losses have to be paid from your initial sum of money or from earnings in other periods.

You will be informed of your income and the income of your seller on an „income screen“. On the screen (see below) the following will be displayed:

- Which seller you traded with

- Which price you offered

- Your desired quality

- The product quality supplied by your seller

- The income of your seller in this period

- Your income in this period.

\begin{tabular}{|l|l|}
\hline Period: & Remaining Time (seconds): \\
\hline & Your ID number: \\
& This offer was accepted \\
& ID of Seller: \\
& Price: \\
& Desired Quality: \\
& Actual Quality: \\
& Income of Seller: \\
& Your Income: \\
& \\
\end{tabular}

Please enter all the information in the documentation sheet supplied to you. After the income screen has been displayed, the respective period is concluded. Thereafter the trading phase of the following period commences. Once you have finished studying the income screen pleas click on the „next“ button.

The sellers also view an income screen which displays the above information. They see the ID of their trading partner, the price, desired and supplied product quality as well as both incomes.

The experiment will not commence until all participants are completely familiar with all procedures. In order to secure that this is the case we kindly ask you to solve the exercises below

In addition we will conduct 2 trials of the trading phase, so that you can get accustomed to the computer. These trial phases will not be added to the result of the experiment and therefore not remunerated. Following the trial phases we will begin the experiment which will last for 15 periods. 


\section{Instructions for Sellers}

You are now taking part in an economic experiment. Please read the following instructions carefully. Everything that you need to know to participate in this experiment is explained below. Should you have any difficulties in understanding these instructions please notify us. We will answer your questions at your cubicle.

At the beginning of the experiment you will receive an initial sum of 10 Swiss Francs. During the course of the experiment you can earn a further amount of money by gaining points. The amount of points that you gain during the experiment depends on your decisions and the decisions of other participants.

All points that you gain during the course of the experiment will be exchanged into Swiss Francs at the end of the experiment. The exchange rate will be:

$$
1 \text { point }=0.10 \text { Swiss Francs }
$$

At the end of the experiment you will receive the sum of money that you earned during the experiment in addition to your 10 Francs initial sum.

The experiment is divided into periods. In each period you have to make decisions which you will enter in a computer. There are 15 periods in all.

Please note that communication between participants is strictly prohibited during the experiment. In addition we would like to point out that you may only use the computer functions which are required for the experiment. Communication between participants and unnecessary interference with computers will lead to exclusion from the experiment. In case you have any questions we shall be glad to assist you.

Prior to the experiment the 17 participants were divided into 2 groups: buyers and sellers. In this experiment there are 10 buyers and 7 sellers.

You shall be a seller for the entire course of the experiment. All participants have received an identification number which they will keep for the entire experiment. Your identification number is stated on the documentation sheet in front of you.

\section{An Overview of the Experiment Procedures}

In each period of the experiment every buyer can trade a product with one seller. The seller earns a profit through the trade when he sells the product at a price which exceeds his production costs. The buyer earns a profit through the trade when the price he pays for the product is less than what it is worth to him. How high the production costs are for the traded product and how much it is worth to the buyer depends on the quality of the product.

The experiment lasts 15 periods. In each period the procedures are as follows:

3. Each period commences with a trading phase which lasts 3 minutes. During this phase buyers can submit trade offers which can be accepted by sellers. When submitting an offer a buyer has to specify three things:

- Which price he offers to pay,

- which product quality he desires,

- and finally, which seller he wants to submit the offer to. Hereby, buyers can submit two types of offers; private offers and public offers. Private offers are submitted to one seller only and can only be accepted by that seller. Public offers are submitted to all sellers and can be accepted by any seller. 
As a buyer you can submit as many offers as you like in each period. Submitted offers can be accepted constantly. Each buyer and each seller can only enter one trade agreement in each period. As there are 10 buyers and 7 sellers, several buyers will not trade in each period.

4. Following the trading phase each seller who has entered a trade agreement then determines which quality of product he will supply to his buyer. Hereby, the seller is not obliged to supply the product quality desired by his buyer. Once every seller has chosen which product quality to supply the points gained by each participant in that period have been determined. After this the next period commences.

The points gained from all 15 periods will be summed up at the end of the experiment, exchanged into Swiss Francs and paid together with your initial sum of money in cash.

\section{The Experiment Procedures in Detail}

There are 10 buyers and 7 sellers in the experiment. You are a seller for the entire course of the experiment. During the experiment you will enter your discussions in a computer. In the following we describe in detail how you can make your decisions in each period.

\section{The Trading Phase}

Each period commences with a trading phase. During the trading phase each buyer can enter into a trading agreement with one seller. In order to do this the buyers can submit trade offers to the sellers. As a seller you can accept in one of the offers submitted to you in each period. During the trading phase you will see the following screen:

\begin{tabular}{|c|c|c|c|c|c|}
\hline Period: & Remaining Time (seconds): \\
\hline \multicolumn{3}{|c|}{ Private offers to you } & public offers \\
\hline buyer & price & des. Q. & buyer & price & des. Q. \\
\hline & & & & & \\
\hline & & & & & \\
\hline \\
\hline
\end{tabular}

- In the top left corner of the screen you will see in which period the experiment is. In the top right corner of the screen you will see the time remaining in this trading phase, displayed in seconds. The trading phase in each period lasts 3 minutes (= 180 seconds). When this time is up the trading phase is over. Hereafter, no further offers can be submitted or accepted for this period. 
- Once you see the above screen displayed the trading phase commences. As a seller you can now accept offers which buyers have submitted to you. There are two types of offers which you can accept:

\section{- Private offers to you}

Each buyer has the opportunity to submit private offers to you. You alone will be informed of these offers and you alone can accept them. No other seller or buyer is informed of these offers. If you receive private offers, they will appear on the left side of your screen, below the title ,private offers to you“. The offer of a buyer will hereby contain the following information: the identification number of the buyer who submitted the offer, the price which he offers for the product and which product quality he desires. If you want to accept a private offer, you click first on the respective row in which the offer is displayed. When you do this the offer will be highlighted. If you are sure you want to accept the offer you then click on the button „accept" which is situated in the bottom left corner of the screen. As long as you do not click ,accept“ you can alter your choice.

\section{- Public offers}

Each buyer also has the possibility to submit public offers. All sellers are informed of these offers and any seller can accept them. If a buyer submits a public offer receive it will appear on the right side of your screen, below the title ,public offers“. The offer of a buyer again contains the identification number of the buyer who submitted the offer, the price which he offers for the product and which product quality he desires. This information is also displayed to all other sellers and all buyers. If you want to accept a public offer you follow the same procedures as with private offers. You click first on the respective row in which the offer is displayed. When you are sure that you want to accept the offer you then click on the button ,accept“ which is situated in the bottom right corner of the screen. As long as you do not click ,accept“ you can alter your choice.

- As soon as you have pressed the „accept“ button you will see which offer you have accepted in the bottom row of your screen.

- Each seller can enter only one trade agreement in each period. Once you have accepted one offer you cannot accept any further offers.

\section{All buyers have to observe the following rules when submitting trade offers:}

- The price offered by the buyer may not be lower than 0 or higher than 100:

$$
0 \leq \text { price } \leq 100
$$

- The desired quality of the buyer may not be below 1 or higher than 10 :

$$
1 \leq \text { desired quality } \leq 10
$$

- Each buyer can submit as many private and public offers as he wishes in each period. Each offer that submitted by a buyer can be accepted at any time during the trading phase.

- Each buyer can enter only one trade agreement in each period. Once an offer of a buyer has been accepted he will be notified which seller accepted it. As each buyer can enter only one trade agreement in each period all other offers of the buyer will be automatically cancelled. Also, he will not be able to submit any further offers.

- Once all 7 sellers have entered a trade agreement or after 3 minutes have eluded, the trading phase is over. 
- No buyer is obliged to submit trade offers, and no seller is obliged to accept a trade offer.

\section{Determination of the Product Quality}

- Following the trading phase, all sellers who have entered a trade-agreement then determine which product quality they will supply to their respective buyers. The product quality desired by your buyer is not binding for you as a seller. You can choose the exact quality desired by your buyer, but also a higher or lower product quality. If you have entered a trade agreement during a trading phase, the following screen will appear for you to enter the product quality:

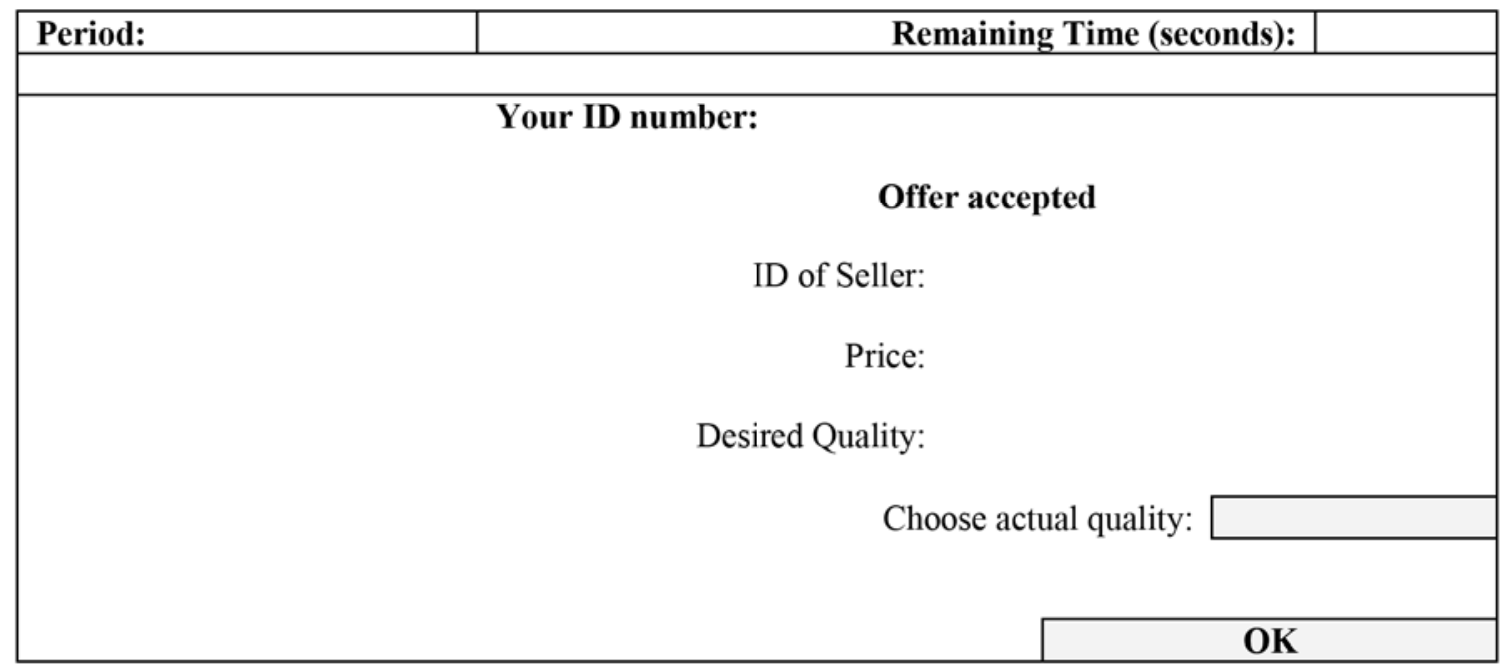

In order to choose the actual product quality, you enter the value for the quality in the field „Determine the actual product quality“ and press the „ok“ button to confirm your choice. As long as you have not pressed „ok“ you can alter your choice.

- The product quality which you choose must be an integer between 1 and 10 .

$$
1 \leq \text { product quality } \leq 10
$$

\section{How are the incomes calculated?}

\section{$\underline{\text { Your income }}$}

- If you have not entered a trade agreement during a trading phase you gain an income of $\mathbf{5}$ points for that period.

- If you have accepted a trade offer your income depends on the price you accepted and the product quality you chose to deliver. Your income will be calculated as follows:

\section{Your income $=$ Price - production costs}

- Your production costs are higher, the higher the quality of the product you chose to deliver. The production costs for each product quality are displayed in the table below:

\begin{tabular}{|l|l|l|l|l|l|l|l|l|l|l|}
\hline Product quality & 1 & 2 & 3 & 4 & 5 & 6 & 7 & 8 & 9 & 10 \\
\hline Production costs & 0 & 1 & 2 & 4 & 6 & 8 & 10 & 12 & 15 & 18 \\
\hline
\end{tabular}


- Your income is therefore higher, the lower the product quality he supplies to you. Further, your income is higher, the higher the price offered by the buyer.

\section{The income of vour buver:}

- If a buyer does not enter a trade agreement during a trading phase he gains an income of 0 points for that period.

- If one of his trade offers is accepted, his income depends on which price he offered and which product quality was supplied to him. The income of your buyer will be determined as follows:

\section{Income of your buyer $=10$ * product quality - price}

- As you can see from the above formula the income of your buyer is higher, the higher the product quality actually supplied by you. At the same time his income is higher, the lower the price he paid for the product.

The income of all buyers and sellers are determined in the same way. Each buyer can therefore calculate the income of his seller and each seller can calculate the income of his buyer. Further, each buyer and seller is informed of the identification number of his trading partner in each period.

Please note that buyers and sellers can incur losses in each period. These losses have to be paid from your initial sum of money or from earnings in other periods.

You will be informed of your income and the income of your buyer on an ,income screen“. On the screen (see below) the following will be displayed:

- Which buyer you traded with

- Which price he offered

- The desired quality of your buyer

- The product quality supplied by you

- The income of your buyer in this period

- Your income in this period.

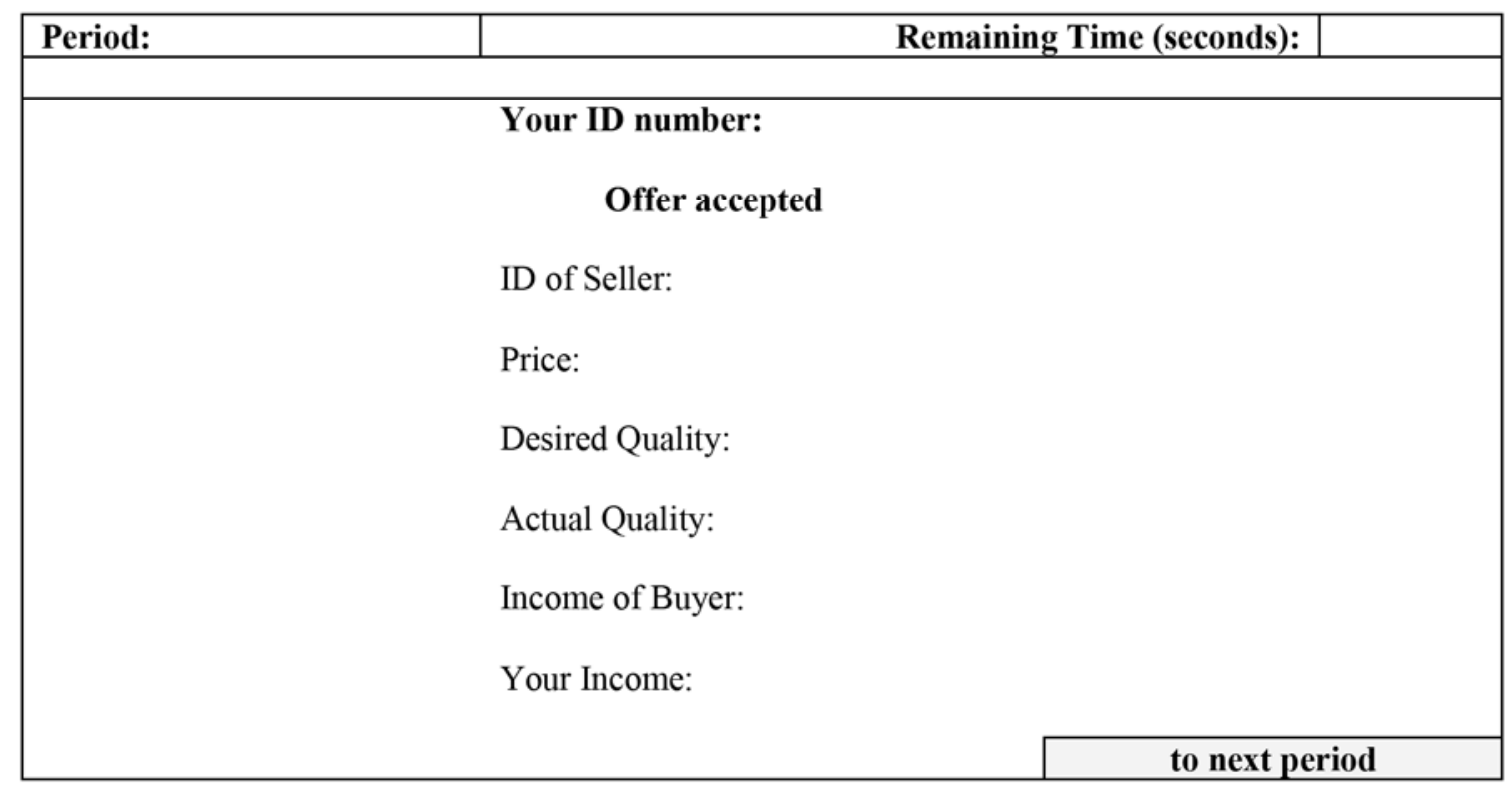


Please enter all the information in the documentation sheet supplied to you. After the income screen has been displayed, the respective period is concluded. Thereafter the trading phase of the following period commences. Once you have finished studying the income screen pleas click on the "next“ button.

The buyers also view an income screen which displays the above information. They see the ID of their trading partner, the price, desired and supplied product quality as well as both incomes.

The experiment will not commence until all participants are completely familiar with all procedures. In order to secure that this is the case we kindly ask you to solve the exercises below

In addition we will conduct 2 trials of the trading phase, so that you can get accustomed to the computer. These trial phases will not be added to the result of the experiment and therefore not remunerated. Following the trial phases we will begin the experiment which will last for 15 periods. 


\section{Swiss National Bank Working Papers published since 2004:}

2004-1 Samuel Reynard: Financial Market Participation and the Apparent Instability of Money Demand

2004-2 Urs W. Birchler and Diana Hancock: What Does the Yield on Subordinated Bank Debt Measure?

2005-1 Hasan Bakhshi, Hashmat Khan and Barbara Rudolf: The Phillips curve under state-dependent pricing

2005-2 Andreas M. Fischer: On the Inadequacy of Newswire Reports for Empirical Research on Foreign Exchange Interventions

2006-1 Andreas M. Fischer: Measuring Income Elasticity for Swiss Money Demand: What do the Cantons say about Financial Innovation?

2006-2 Charlotte Christiansen and Angelo Ranaldo: Realized Bond-Stock Correlation: Macroeconomic Announcement Effects

2006-3 Martin Brown and Christian Zehnder: Credit Reporting, Relationship Banking, and Loan Repayment

2006-4 Hansjörg Lehmann and Michael Manz: The Exposure of Swiss Banks to Macroeconomic Shocks - an Empirical Investigation

2006-5 Katrin Assenmacher-Wesche and Stefan Gerlach: Money Growth, Output Gaps and Inflation at Low and High Frequency: Spectral Estimates for Switzerland

2006-6 Marlene Amstad and Andreas M. Fischer: Time-Varying Pass-Through from Import Prices to Consumer Prices: Evidence from an Event Study with Real-Time Data

2006-7 Samuel Reynard: Money and the Great Disinflation

2006-8 Urs W. Birchler and Matteo Facchinetti: Can bank supervisors rely on market data? A critical assessment from a Swiss perspective

2006-9 Petra Gerlach-Kristen: A Two-Pillar Phillips Curve for Switzerland

2006-10 Kevin J. Fox and Mathias Zurlinden: On Understanding Sources of Growth and Output Gaps for Switzerland

2006-11 Angelo Ranaldo: Intraday Market Dynamics Around Public Information Arrivals

2007-1 Andreas M. Fischer, Gulzina Isakova and Ulan Termechikov: Do FX traders in Bishkek have similar perceptions to their London colleagues? Survey evidence of market practitioners' views 
2007-2 Ibrahim Chowdhury and Andreas Schabert: Federal Reserve Policy viewed through a Money Supply Lens

2007-3 Angelo Ranaldo: Segmentation and Time-of-Day Patterns in Foreign Exchange Markets

2007-4 Jürg M. Blum: Why `Basel II’ May Need a Leverage Ratio Restriction

2007-5 Samuel Reynard: Maintaining Low Inflation: Money, Interest Rates, and Policy Stance

2007-6 Rina Rosenblatt-Wisch: Loss Aversion in Aggregate Macroeconomic Time Series

2007-7 Martin Brown, Maria Rueda Maurer, Tamara Pak and Nurlanbek Tynaev: Banking Sector Reform and Interest Rates in Transition Economies: Bank-Level Evidence from Kyrgyzstan

2007-8 Hans-Jürg Büttler: An Orthogonal Polynomial Approach to Estimate the Term Structure of Interest Rates

2007-9 Raphael Auer: The Colonial Origins Of Comparative Development: Comment. A Solution to the Settler Mortality Debate

2007-10 Franziska Bignasca and Enzo Rossi: Applying the Hirose-Kamada filter to Swiss data: Output gap and exchange rate pass-through estimates

2007-11 Angelo Ranaldo and Enzo Rossi: The reaction of asset markets to Swiss National Bank communication

2007-12 Lukas Burkhard and Andreas M. Fischer: Communicating Policy Options at the Zero Bound

2007-13 Katrin Assenmacher-Wesche, Stefan Gerlach, and Toshitaka Sekine: Monetary Factors and Inflation in Japan

2007-14 Jean-Marc Natal and Nicolas Stoffels: Globalization, markups and the natural rate of interest

2007-15 Martin Brown, Tullio Jappelli and Marco Pagano: Information Sharing and Credit: Firm-Level Evidence from Transition Countries

2007-16 Andreas M. Fischer, Matthias Lutz and Manuel Wälti: Who Prices Locally? Survey Evidence of Swiss Exporters

2007-17 Angelo Ranaldo and Paul Söderlind: Safe Haven Currencies 
2008-1 Martin Brown and Christian Zehnder: The Emergence of Information Sharing in Credit Markets

2008-2 Yvan Lengwiler and Carlos Lenz: Intelligible Factors for the Yield Curve

2008-3 Katrin Assenmacher-Wesche and M. Hashem Pesaran: Forecasting the Swiss Economy Using VECX* Models: An Exercise in Forecast Combination Across Models and Observation Windows

2008-4 Maria Clara Rueda Maurer: Foreign bank entry, institutional development and credit access: firm-level evidence from 22 transition countries

2008-5 Marlene Amstad and Andreas M. Fischer: Are Weekly Inflation Forecasts Informative?

2008-6 Raphael Auer and Thomas Chaney: Cost Pass Through in a Competitive Model of Pricing-to-Market

2008-7 Martin Brown, Armin Falk and Ernst Fehr: Competition and Relational Contracts: The Role of Unemployment as a Disciplinary Device 
Swiss National Bank Working Papers are also available at www.snb.ch, section Publications/Research Subscriptions or individual issues can be ordered at Swiss National Bank, Fraumünsterstrasse 8, CH-8022 Zurich, fax +41446318114, E-mail library@snb.ch 